\title{
Sea ice, extremophiles and life on extra-terrestrial ocean worlds
}

\author{
Andrew Martin and Andrew McMinn \\ Institute for Marine and Antarctic Studies, University of Tasmania, Tasmania, Australia e-mail: andrew.martin@utas.edu.au
}

\begin{abstract}
The primary aim of this review is to highlight that sea-ice microbes would be capable of occupying ice-associated biological niches on Europa and Enceladus. These moons are compelling targets for astrobiological exploration because of the inferred presence of subsurface oceans that have persisted over geological timescales. Although potentially hostile to life in general, Europa and Enceladus may still harbour biologically permissive domains associated with the ice, ocean and seafloor environments. However, validating sources of free energy is challenging, as is qualifying possible metabolic processes or ecosystem dynamics. Here, the capacity for biological adaptation exhibited by microorganisms that inhabit sea ice is reviewed. These ecosystems are among the most relevant Earth-based analogues for considering life on ocean worlds because microorganisms must adapt to multiple physicochemical extremes. In future, these organisms will likely play a significant role in defining the constraints on habitability beyond Earth and developing a mechanistic framework that contrasts the limits of Earth's biosphere with extra-terrestrial environments of interest.
\end{abstract}

Received 27 April 2016, accepted 18 November 2016, first published online 10 February 2017

Key words: analogue, Enceladus, Europa, extremophilic microorganisms, habitability, ocean planet.

\section{Introduction}

Microorganisms preside in every ecological niche on Earth: from the tropics to the poles, from underground mines and oil fields to the stratosphere and mountain ranges; from deserts to the Dead Sea, and hot springs to underwater hydrothermal vents (e.g. Junge et al. 2002; Nagy et al. 2005; McCliment et al. 2006; Soo et al. 2009). Microbes dominate the flux of energy and biologically important chemical cycles in the world's oceans and are estimated to have a biomass five to ten times that of all multicellular marine organisms (Pomeroy et al. 2007). The number of bacteria alone is estimated to be $10^{29}$ (Whitman et al. 1998), which is more than the $10^{24}$ stars in the observable Universe (van Dokkum \& Conroy 2010). Considering that microbes existed on Earth $\sim 3 \mathrm{Ga}$ before the evolution of land plants (Runnegar 1992) and that animals appeared a mere 600 million years ago, the diversity and metabolic plasticity of microscopic life is not considered surprising (Staley \& Gosink 1999). However, from a molecular perspective, this assemblage harbours much that remains unknown; not only are these cells a potential source of useful genes for medicine and biotechnology, but unravelling the taxonomic complexities of prokaryotes is considered the key to understanding the process of evolution (Pace 1997; Pedrós-Alió 2006). Microorganisms are no less relevant in the consideration of extra-terrestrial life within our Solar System and beyond. If it is assumed that abiogenesis results in cellular life - that proto-biochemistry can be considered a 'cosmic imperative' regardless of variation in biogenic elements (see de Duve 1995; Deamer \& Weber 2010; Stüeken et al. 2013) - then the prokaryotic cell is potentially a universal blueprint for life.
Furthermore, if life on Earth can be considered a valid analogue, then the origin and subsequent development of any extra-terrestrial ecosystem will, to a greater or lesser extent, be characterized by its microbial community. Alternatively, if physicochemical conditions on extra-terrestrial worlds such as Mars or Europa cannot support the emergence of life, in any form, then the clues to habitability revealed by Earth's microbial consortia may be considered largely irrelevant (Dartnell 2011).

Defining the requirements and physiological limits to habitability in Earth's most extreme environments has provided a significant stimulus for the field of astrobiology (e.g. Hart 1978; Hoyle et al. 1982; Kasting et al. 1993; Gaidos et al. 1999; Chyba \& Phillips 2001; Martin et al. 2008; McKay 2014). Although a consensus on the origin, timing and specific location for the emergence of life on Earth is currently lacking (Lederberg 1960; Davis \& McKay 1996; Chyba et al. 2000), organisms that have adapted to physiological extremes are thought to provide insight into the habitability of extra-terrestrial systems (Hoover \& Pikuta 2009; McKay 2014). Here, we adopt the binary definition of habitability recently coined by Cockell et al. (2016) whereby a habitat is 'an environment capable of supporting the activity of at least one known organism'. Although conservative, this construct is useful because it is not necessary to define 'life' and speculating on the capacities of unknown organisms is avoided. Closely coupled with the existence of habitable conditions is the extent of habitability; this provides context for the type of organisms present and the time period over which they can be sustained (Cockell et al. 2016). An organism that is capable of growth and reproduction 
within an environmental niche deemed detrimental to most life on Earth is classified as an extremophile. The biological interpretation of 'extreme' requires caveats (for a review see Rothschild \& Mancinelli 2001), but the concept is particularly useful in linking adaptive responses and survival thresholds to physical (e.g. pressure, temperature and radiation) and geochemical (e.g. pH, salinity and desiccation) extremes. An overview of the key abiotic stressors, biological nomenclature and adaptive responses is provided in Table 1. Life on Earth requires two forms of energy: thermal energy for melting water and chemical energy for the maintenance and regulation of life processes (Hand et al. 2007). Of these two fundamental requirements, it is the presence of liquid water that is most likely to limit habitable extra-terrestrial environments because its occurrence in our Solar System is limited (McKay 2014). Life on Earth requires a fluid medium that dissolves molecules and facilitates the three-dimensional (3D) shape and catalytic function of enzymes (Chyba et al. 2000).

Examples of previously unexpected microbial ecosystems that are of relevance to astrobiology include deep-sea sulphide-rich hydrothermal vents (Corliss et al. 1979; Spiess et al. 1980), deep-sea methane $\left(\mathrm{CH}_{4}\right)$ - and hydrogen-rich vents (Kelley et al. 2001), groundwater some $2.8 \mathrm{~km}$ below the Earth's surface (Lin et al. 2006), microbes dwelling within basalt rock (Stevens \& McKinley 1995), sediments at Challenger Deep $(\sim 10900 \mathrm{~m})$ in the Mariana Trench (Glud et al. 2013), Lake Vida, an ice-covered Antarctic lake that has been isolated for thousands of years (Murray et al. 2012) and Arctic cryopeg brines, which have been geologically isolated in permafrost for hundreds to millions of years (Gilichinsky et al. 2003; Colangelo-Lillis et al. 2016). Invariably, it is members of the Archaea and Bacteria that are found in these environments, but a range of eukaryotes, polar diatoms and tardigrades for example, also exhibit robust responses to biologically challenging environments. Of particular relevance to astrobiology are polyextremophiles, organisms that are capable of tolerating more than one physiochemical extreme (Rothschild \& Mancinelli 2001). The celestial bodies within our Solar System, which could potentially support life due to the presence of water are highlighted in Table 2, and a number of these are targets in the Ocean Worlds Exploration Program recently proposed by NASA (Anderson 2016). Here, we review the suite of adaptations exhibited by polyextremophiles that inhabit sea ice at Earth's polar regions. These dynamic ecosystems are among the most relevant Earth-based analogues for considering life on ice-associated ocean worlds (Deming \& Eicken 2007). In a previous review, Deming \& Eicken (2007) discussed the characteristics of liquid water in ice and how they influence the abundance and activity of microbial life. The primary aim of this review is to highlight that sea-ice microbes would be capable of occupying specific niches on the moons of Europa and Enceladus.

\section{Sea ice}

Although it is mostly an ephemeral habitat, seasonal sea ice covers up to $26 \times 10^{6} \mathrm{~km}^{2}$ of the Earth's surface (Parkinson
2014) and represents one of the planet's major biomes (Thomas \& Dieckmann 2002a; Arrigo 2014). Biological elements, including viruses, bacteria and microalgae are initially scavenged from the water column during ice formation, and are then confined to a labyrinth of pores and brine channels that vary in size from micrometres to several millimetres within a semi-solid freshwater matrix (Garrison 1991; Thomas \& Dieckmann 2002b; Arrigo \& Thomas 2004). For microbial communities, the ice matrix represents a challenging physicochemical environment with oscillating gradients in temperature, salinity, $\mathrm{pH}$, dissolved inorganic nutrients, as well as dissolved gas and light signatures (Mock \& Thomas 2005). Only a subset of the initial inoculum, those bacteria and microalgae deemed to be polyextremophiles, are capable of growing within sea ice. Biological production reflects a complex relationship between physical ice dynamics, the distribution of organic and inorganic nutrients, light and ultraviolet (UV) radiation and the biological structure of the sea-ice microbial community - all of which modifies the in situ cycling of energy (Arrigo \& Sullivan 1992; Vaqué et al. 2002; Stewart \& Fritsen 2004). Despite the implications for being a seasonally dynamic habitat, sea-ice microbiology was considered to be in its infancy at the turn of the century (Staley \& Gosink 1999) and significant questions still remain regarding the molecular basis for biochemical and physiological adaptation (Mock \& Thomas 2005; Koh et al. 2012; Ewert \& Deming 2013; Lyon \& Mock 2014). In 2002, the term eutectophile was introduced by microbiologist Deming (2002). Pertaining to eutectic, which describes the interface between solid and liquid phases of water, this term does not classify an ice-associated microbe by a single physicochemical variable, but by whatever known, and currently unknown, combination of variables influence life processes in a habitat defined by both solid and liquid phases of water. Heterotrophic bacteria and unicellular algae represent the two major eutectophilic groups within sea-ice assemblages and will be the focus of this review.

\section{Temperature}

The Earth is a cold planet and many organisms are exposed to temperatures that are permanently below $5^{\circ} \mathrm{C}$ (Russell 2000; Margesin \& Miteva 2011; Lyon \& Mock 2014). At sub-zero temperatures, water freezes and the resulting ice crystals can tear cell membranes; unless cells are cryopreserved using flash-freeze techniques (see Dumont et al. 2004), freezing of intracellular water is almost invariably lethal (Lorv et al. 2014). Despite the negative effect of low temperature on biochemical reactions, numerous organisms, in particular bacteria, yeasts, unicellular algae and fungi can successfully adapt to cold environments (Gerday et al. 2000; Gerday 2013). Most are either psychrotolerant (capable of growth close to the freezing point of water; fastest growth occurs at $>20^{\circ} \mathrm{C}$ ) or psychrophilic (fastest growth occurs at $\leq 15^{\circ} \mathrm{C}$; growth is not possible $>20^{\circ} \mathrm{C}$ ) (Cavicchioli et al. 2002) with generation times that range from $2 \mathrm{~h}$ to 10 days (Gerday et al. 2000). Here the term psychrophile is used in a generic sense to describe all microorganisms capable of growth in 
Table 1. Classification and examples of extremophiles

\begin{tabular}{|c|c|c|c|c|}
\hline $\begin{array}{l}\text { Physicochemico } \\
\text { extreme }\end{array}$ & $\begin{array}{l}\text { Biological } \\
\text { classification }\end{array}$ & Definition & Adaptation & $\begin{array}{l}\text { Example of biotope (known mi- } \\
\text { crobial extreme) }\end{array}$ \\
\hline \multirow[t]{2}{*}{ Dessiccation } & Hypolith & $\begin{array}{l}\text { Resides underneath rocks in } \\
\text { cold deserts }\end{array}$ & $\begin{array}{l}\text { Low metabolism, slow growth, } \\
\text { small populations }\end{array}$ & $\begin{array}{l}\text { Cornwallis Island, Devon Island, } \\
\text { Canadian high Arctic }\end{array}$ \\
\hline & Xerophile & $\begin{array}{l}\text { Capable of growth with limited } \\
\text { water }\end{array}$ & $\begin{array}{l}\text { Increased internal osmolarity, } \\
\text { DNA stability (protein binding } \\
\text { and repair) }\end{array}$ & Atacama Desert, South America \\
\hline Habitat & Cryptoendolith & $\begin{array}{l}\text { Inhabits interstitial space within } \\
\text { rocks }\end{array}$ & $\begin{array}{l}\text { Utilize gas or dissolved nutrients } \\
\text { from water moving through frac- } \\
\text { tured rock }\end{array}$ & Dry Valleys, Antarctica \\
\hline \multirow[t]{2}{*}{ Metabolism } & Anaerobe & Grows without oxygen & $\begin{array}{l}\text { Fermentation, anaerobic respir- } \\
\text { ation, bacterial photosynthesis, or } \\
\text { methanogenesis }\end{array}$ & Black Sea subsurface sediments \\
\hline & Lithoautotroph & $\begin{array}{l}\text { Derives energy from reduced } \\
\text { compounds of mineral origin }\end{array}$ & $\begin{array}{l}\text { ATP produced by inorganic com- } \\
\text { pounds: } \mathrm{H}_{2}, \mathrm{CO}, \mathrm{NH}_{3}, \mathrm{NO}_{2}, \mathrm{H}_{2} \mathrm{~S} \\
\text { or } \mathrm{S}, \mathrm{FE}^{++}\end{array}$ & Yelowstone National Park, USA \\
\hline Metals & Metallotolerant & Tolerates dissolved heavy metals & $\begin{array}{l}\text { Selective metal accumulation; de- } \\
\text { toxification mechanisms }\end{array}$ & $\begin{array}{l}\text { Mining and industrial waste (e.g. } \\
\text { mercury- cadmium-resistant } \\
\text { bacteria) }\end{array}$ \\
\hline Nutrients & Oligotroph & $\begin{array}{l}\text { Capable of growth in low nutri- } \\
\text { ent environments }\end{array}$ & $\begin{array}{l}\text { Low metabolism, slow growth, } \\
\text { small populations }\end{array}$ & Lake Vostok, Antarctica \\
\hline \multirow[t]{2}{*}{$\mathrm{pH}$} & Acidophile & Growth optima at $\mathrm{pH} \leq 3$ & $\begin{array}{l}\text { Cell cytoplasm maintained at } \\
\text { neutral } \mathrm{pH} \text {, or proteins exhibit acid } \\
\text { stability }\end{array}$ & Iron Mountain mine, USA $(\mathrm{pH} 0)$ \\
\hline & Alkaphile & Growth optima at $\mathrm{pH} \geq 9$ & $\begin{array}{l}\text { Cell cytoplasm maintained at } \\
\text { neutral } \mathrm{pH}\end{array}$ & $\begin{array}{l}\text { Slag dumps, Chicago, USA (pH } \\
12.8 \text { ) }\end{array}$ \\
\hline Pressure & Piezophile & $\begin{array}{l}\text { Capable of growth at high } \\
\text { pressure }\end{array}$ & $\begin{array}{l}\text { Increased fluidizing fatty acids in } \\
\text { cell membranes }\end{array}$ & $\begin{array}{l}\text { Deep-sea habitats below } 2000 \mathrm{~m} \\
(200 \mathrm{MPa})\end{array}$ \\
\hline adiation & Radioresistant & $\begin{array}{l}\text { Resistant to high levels of ioniz- } \\
\text { ing radiation }\end{array}$ & $\begin{array}{l}\text { Multiple copies of genome, rapid } \\
\text { DNA repair mechanisms }\end{array}$ & $\begin{array}{l}\text { Radioactive waste from mining } \\
\text { (uranium respiration) }\end{array}$ \\
\hline Salinity & Halophile & $\begin{array}{l}\text { Growth requires salt }(\mathrm{NaCl}, \\
\geq 0.2 \mathrm{M})\end{array}$ & $\begin{array}{l}\text { Accumulation of osmoprotec- } \\
\text { tants, or selective influx of } \mathrm{K}^{+} \text {ions } \\
\text { into cytoplasm }\end{array}$ & $\begin{array}{l}\text { Don Juan Pond, Wright Valley, } \\
\text { Eastern Antarctica (salinity } \sim 40 \% \\
\text { by mass) }\end{array}$ \\
\hline \multirow[t]{2}{*}{ Temperature } & Hyperthermophile & $\begin{array}{l}\text { Growth optima between } 80 \text { and } \\
121^{\circ} \mathrm{C}\end{array}$ & $\begin{array}{l}\text { Protein molecules that maintain } \\
\text { stuctural stability/function }\end{array}$ & $\begin{array}{l}\text { Juan de Fuca Ridge, Pacific Ocean } \\
\left(121^{\circ} \mathrm{C}\right)\end{array}$ \\
\hline & Psychrophile & $\begin{array}{l}\text { Growth in the temperature } \\
\text { range }-20 \text { and } 10^{\circ} \mathrm{C}\end{array}$ & $\begin{array}{l}\text { Cell membranes resistant to stif- } \\
\text { fening, antifreeze proteins, cold- } \\
\text { adapted enzymes }\end{array}$ & Antarctic/Arctic sea ice $\left(-20^{\circ} \mathrm{C}\right)$ \\
\hline $\begin{array}{l}\text { Temperature/ } \\
\text { pH }\end{array}$ & Thermoacidophile & $\begin{array}{l}\text { Prefers temperatures of } 70 \text { and } \\
80^{\circ} \mathrm{C} \text { and } \mathrm{pH} \text { from } 2 \text { to } 3\end{array}$ & $\begin{array}{l}\text { Cell membranes with low proton } \\
\text { permeability, acid and heat stable } \\
\text { extracellular enzymes }\end{array}$ & $\begin{array}{l}\text { Deep sea hydrothermal vents } \\
\left(95^{\circ} \mathrm{C} / \mathrm{pH} 1.0\right)\end{array}$ \\
\hline
\end{tabular}

cold environments. In Arctic and Antarctic marine habitats, seawater and sediment temperatures can drop to approximately $-2{ }^{\circ} \mathrm{C}$; within sea-ice internal fluids typically range from -2 to $-30^{\circ} \mathrm{C}$ (Ewert \& Deming 2013). The lowest temperature recorded for active in situ photosynthesis by sea-ice algae is currently $-10^{\circ} \mathrm{C}$ (Ralph et al. 2005). Although the tolerance of cold-adapted bacteria appears to be highly variable, in vitro heterotrophic activity has been observed at temperatures as low as $-33^{\circ} \mathrm{C}$ (Bakermans \& Skidmore 2011). The cold completely permeates microorganisms in these environments and all components of the cell - membranes and transport systems, intracellular solutes, nucleic acids and proteins - must be suitably adapted (Cavicchioli et al. 2002; Morgan-Kiss et al. 2006). The physiological and ecological success of psychrophiles is thought to reflect an ability to sense temperature change in the environment (Margesin \& Miteva 2011). In bacteria, the sensor transduces the signal to the genome, subsequently upregulating genes whose products are associated with cold adaptation (Shivaji \& Prakash 2010). This includes regulating membrane fluidity, maintaining protein synthesis, producing cold-acclimation proteins and facilitating freeze tolerance or avoidance mechanisms (Feller \& Gerday 2003; Gerday 2013). Given sufficient time, the metabolic plasticity of psychrophiles facilitates acclimation to ranging polar temperatures (Mock \& Hoch 2005).

\section{Membrane fluidity}

The ability to retain a functional lipid bilayer is an important low-temperature requirement because cell membranes control the transport of nutrients and metabolic waste products in and out of the cell (Thomas \& Dieckmann 2002a; Lyon \& Mock 2014). The functional state of this bilayer is a liquidcrystalline phase, but decreased temperatures induce a gelphase transition and a dramatic loss of membrane properties. Importantly, the temperature at which this occurs is dependent on the lipid composition of the membrane (Feller \& Gerday 


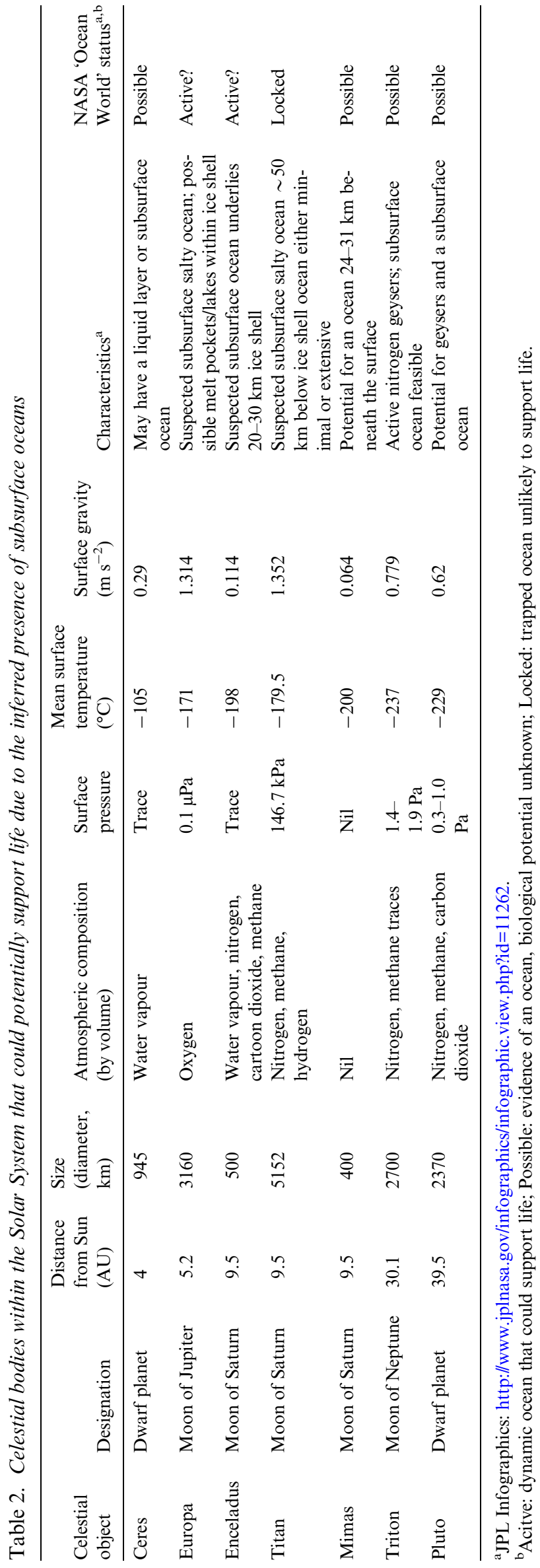

2003). In order to maintain fluidity, organisms utilize a combination of changes in fatty acid composition, including polyunsaturated, short-chain, branched or cyclic fatty acids (White et al. 2000; Mock \& Thomas 2005). One of the well-documented responses, the increase in polyunsaturated fatty acids (PUFAs), has been observed in polar bacteria (Nichols et al. 1999; Russell \& Nichols 1999) diatoms (Torstensson et al. 2013), dinoflagellates (Thomson et al. 2004) and chlorophytes (Chen et al. 2012). Increases in polyunsaturated bonds promote a looser packing of lipids, which decreases the gelphase transition (Lyon \& Mock 2014). Although the sensory and signal pathways involved in PUFA synthesis are unknown in polar microalgae (Lyon \& Mock 2014), membrane fluidity is connected with optimal photosynthesis at low temperature, specifically the correct folding of membrane-associated proteins, which form the photosynthetic electron transport chain (Morgan-Kiss et al. 2006).

\section{Cold-adapted enzymes}

Most of the chemical reactions that occur in living organisms are catalysed by enzymes (Gerday 2013). Because microbes are organisms with variable internal temperatures, in cold environments enzymes must overcome the inhibiting effects of low kinetics, specifically the freezing of molecules and decreased rates of catalysis (Casanueva et al. 2010; Lyon \& Mock 2014). The molecular adaptation of enzymes to compensate for reduced reaction rates is considered a critical feature of cold-adapted microbes (Russell 1997; Gerday et al. 2000; Morgan-Kiss et al. 2006). These enzymes are characterized as having a high catalytic efficiency at low temperatures, high degrees of thermolability and increased structural flexibility for better substrate access (Thomas \& Dieckmann 2002a; Feller \& Gerday 2003; Siddiqui \& Cavicchioli 2006; Struvay $\&$ Feller 2012). Numerous enzymes have now been characterized and high activity/low stability appears to underlie a general principle of activity-stability trade-off in cold-adapted enzymes (Siddiqui \& Cavicchioli 2006; Collins et al. 2008). Relative to the enzymes found in thermophilic cells, coldadapted enzymes exhibit (a) an optimum temperature that is displaced towards low temperatures by as much as $30^{\circ} \mathrm{C}$, (b) catalytic efficiency that is close to the apparent optimum and (c) rapid inactivation at temperatures $>25^{\circ} \mathrm{C}$ (Russell 2000; Gerday 2013). Cold-adapted proteins are produced with relatively minor changes in amino acid sequences and no dramatic differences in 3D structure, but they can be up to ten times more active at low and moderate temperatures (Feller 2003; Margesin \& Miteva 2011; Gerday 2013). For example, coldadapted proteases are produced by the psychrophilic bacterium Colwellia psychrerythraea 34H (Huston et al. 2000), but the adaptation does not appear to correlate with a unique set of genes (Methé et al. 2005). Furthermore, genome analysis of C. psychrerythraea predicts that a significant percentage of the enzymes associated with protein and peptide degradation are localized external to the cytoplasm. Other extracellular compounds will be discussed subsequently, but the capacity to synthesize cold-adapted degradative enzymes has important implications for astrobiology because of the like requirement 
for substrate modification in cold environments. Interestingly, ribulose-1,5-bisphosphate carboxylase/oxygenase (RUBISCO), one of the key enzymes associated with photosynthesis, is not modified by psychrophilic microalgae; instead, these organisms attempt to compensate by increasing intracellular enzyme concentration (Devos et al. 1998). The reason why polar microalgae cannot modify RUBISCO remains unknown, but the energetic cost of production appears to significantly constrain carbon fixation in Antarctic diatoms (Young et al. 2015a). Applications for cold-adapted enzymes in biotechnology are being explored (Cavicchioli et al. 2002; Marx et al. 2007; Struvay \& Feller 2012).

\section{Cryoprotectants}

Cellular freezing, as it occurs on Earth, induces the formation of cytoplasmic ice crystals, which leads to osmotic imbalance and cellular damage. Cold-loving organisms prevent this by utilizing 'chemical chaperones', compatible solutes such as polyols, polyamines, sugars and amino acid derivatives, which function as freeze protection molecules. The function of these compounds is to prevent the denaturation and aggregation of proteins and reduce the freezing point, thereby maintaining high in vivo enzymatic activity (Shivaji \& Prakash 2010; Lyon \& Mock 2014). Of particular interest is the amino acid derivative dimethylsulfoniopropionate (DMSP), which is produced in high concentrations by sea-ice algae for reasons that are not entirely clear. DMSP may play a role in stabilizing enzymes against cold-induced denaturation (Nishiguchi \& Somero 1992), but there is also evidence to suggest that it acts as a grazing deterrent via its cleavage to acrylate (Mock \& Thomas 2005; Fredrickson \& Strom 2009), and, due to a rapid reaction with the hydroxyl radical $(\mathrm{OH})$, it may also serve as an antioxidant system by actively scavenging intracellular $\mathrm{OH}^{-}$(Sunda et al. 2002). Interestingly, the intracellular concentration of DMSP is influenced by light, nutrients and pH in many algal taxa (Marlin \& Kirst 1997), while its enzymatic cleavage product dimethylsulphide (DMS) contributes significantly to the global sulphur cycle (Welsh 2000; Arrigo \& Thomas 2004; Kloster et al. 2006; Sievert et al. 2007).

Some psychrophiles produce antifreeze or ice-binding proteins (IBPs), which are characterized by their capacity to cause a temperature difference in the melting and freezing of ice (Celik et al. 2013). These proteins effectively modify ice crystal structure and inhibit recrystallization of ice within the cell (Gilbert et al. 2004; De Maayer et al. 2014). Exposure to low temperatures elicits the up- or down-regulation of a significant number of genes in psychrophiles, a process termed the cold-shock response (Casanueva et al. 2010). Although a mechanistic understanding of this processes is lacking, the genes prominently up-regulated in cold-adapted organisms code for cold-shock proteins that regulate a variety of cellular processes, including transcription, translation, protein folding and membrane fluidity (Hébraud \& Potier 1999; Phadtare 2004).

\section{Extracellular compounds}

When exposed to sub-zero temperatures, it is important for ice-associated microbes to maintain an aqueous external environment. Effective micro-habitat modifiers produced within the ice matrix include IBPs and extracellular polymeric substances (EPS), which act as cryoprotectants (Mock \& Thomas 2005). Also known as ice-active substances, IBPs (and EPS) enhance brine retention by inhibiting ice growth and recrystallization in the immediate vicinity of the cell (Krembs et al. 2011; Davies 2014). This improves the habitability of the ice by preventing injury during freezing (Raymond \& Knight 2003), trapping and protecting pockets of saline water within brine channels (Krembs et al. 2011) and potentially facilitating the attachment of cells to adjacent ice crystals (Raymond \& Kim 2012; Ulig et al. 2015). To date, all sea-ice algae that have been tested (diatoms, prymnesiophytes, prasinophytes and chlorophytes) have been shown to produce IBPs (Lyon \& Mock 2014), and phylogenetic analysis suggests that the required genes were obtained through the horizontal gene transfer of bacterial IBPs (Raymond \& Kim 2012; Davies 2014; Raymond 2014). The EPSs produced by sea-ice microbes (known also as extracellular polysaccharide substances; both abbreviated as EPS) are gel-like muscilages composed of complex organic macromolecules that have a high surface area comprising carbohydrates (both mono- and polysaccharides), amino acids and proteins (Decho 1990; Underwood et al. 2010). Because different bacterial and algal strains produce EPS with varying physical and chemical structures, the behaviour of these microbial exudates in aqueous solution is complex (Krembs et al. 2011). The term refers to a diverse range of polysaccharides and ancillary compounds (Ewert \& Deming 2013) and there has been significant ambiguity in defining and also analysing EPS. However, the presence of EPS within the seaice matrix highlights a significant adaptive response to a range of stressors. Similar to IBPs, these polymers modify brine channel habitability (Krembs et al. 2002, 2011; Underwood et al. 2010, 2013), but they also provide a viscous media that keeps extracellular enzymes in the vicinity of the cell and are likely to facilitate cell adhesion and motility within brine channels (Krembs \& Deming 2008). Additional advantages of microbial EPS production include protection from toxic heavy metals (Ozturk \& Aslim 2010) and the prevention of desiccation in a high-saline environment (Thomas \& Dieckmann 2002a; Aslam et al. 2012a; Steele et al. 2014).

\section{Salinity}

Closely related to sub-zero temperature tolerance is the physiological challenge of salt stress and the adaptive responses elicited by halophiles. Because salinity within the ice matrix is a function of temperature, microbes constrained to brine channels near the upper surface of the ice can be exposed to saline concentrations $>200 \%$ (Kottmeier \& Sullivan 1988; Arrigo \& Sullivan 1992; Mock 2002), while the onset of ice melt rapidly exposes cells to freshwater lenses where the salinity can be as low as $0 \%$ (Thomas \& Dieckmann 2002a). In addition to these extreme seasonal events, both the salinity and interstitial brine volume fraction can fluctuate over timescales of a few hours to several days (Ewert \& Deming 2014), which necessitates a dynamic response from ice-associated microbes. 
Physiological activity is challenged by both hyper- and hyposalinity, and in sea-ice algae this ranges from reduced photosynthetic efficiency and capacity (Ryan et al. 2004; Ralph et al. 2007; Steele et al. 2014) to enzyme damage and cell lysis (Ewert \& Deming 2014). Although sea-ice algae can be physiologically active at saline concentrations ranging from 10 to $80 \%$, maximum photosynthesis occurs at salinities between 30 and 50\%o (Arrigo \& Sullivan 1992; Ryan et al. 2004; Ralph et al. 2007). Sea-ice bacteria appear to be more tolerant of ambient salt concentrations given that sustained metabolic activity has been observed at $20-70 \%$ while maintaining an incubation temperature of $-1.8^{\circ} \mathrm{C}$ (Martin et al. 2009).

\section{Compatible solutes}

High osmolarity of the brine phase imposes two distinct constraints on microbial life: impaired protein function which, if exacerbated, can lead to protein precipitation, and increased osmotic pressure, which can result in dehydration and a reduction in cell volume (Krell et al. 2007; Ewert \& Deming 2013). In response to highly saline conditions, osmolytes, including inorganic ions and organic solutes (e.g. proline, mannitol and glycine betaine) are accumulated or synthesized within the cell (Thomas \& Dieckmann 2002a; Ewert \& Deming 2014). Conversely, hyposaline shock can be alleviated by releasing osmolytes to the external environment. In general, the accumulation of compatible solutes in halotolerant and halophilic organisms assists with the maintenance of turgor pressure, cell volume and intracellular electrolytes - all of which are important for cell proliferation (Roberts 2005). However, these mechanisms are energetically expensive and the disturbance of cellular homeostasis due to the influx or efflux of ions can result in a temporary decline in growth and cell division (Krell et al. 2007). Fluctuating water potential is also a stimulus for the production of bacterial EPS (Chang \& Halverson 2003; Chang et al. 2007; Ozturk \& Aslim 2010), but only recently has a similar response been demonstrated in sea-ice algae (Aslam et al. 2012b; Steele et al. 2014; Ugalde et al. 2014). Microscale environmental buffering with EPS provides a hydrated environment around the cell, which is highly beneficial and likely to be strongly selected for following initial ice formation (Krembs \& Deming 2008). Indeed, the regional significance of EPS within sea ice is such that it can be accurately predicted from physical-biogeochemical models that use ice thickness, salinity and algal biomass as core variables (Underwood et al. 2013).

\section{Light}

Ice-associated microbes are exposed to a highly variable light regime, from extremely low seasonal irradiance at the bottom of the ice matrix to doses of both visible and UV-B radiation near the ice surface that can cause physiological damage (Martin et al. 2009; McMinn \& Martin 2013; Arrigo 2014). Because of high light attenuation by sea ice and the presence of surface snow, midday summer irradiance beneath the ice can be as low as $1-2 \%$ of the incident surface irradiance (Cota 1985; McMinn et al. 1999a). Low light stress is therefore common in photosynthetic microbes. However, the capacity for sea-ice algae to harvest light is remarkable; active photosynthesis has been observed at irradiances $<0.5 \mu \mathrm{E} \mathrm{m}^{-2} \mathrm{~s}^{-1}$, or $0.01 \%$ of incident surface irradiance (Palmisano \& Sullivan 1983), and complete photosynthetic saturation has been demonstrated at $<10 \mu \mathrm{E} \mathrm{m}^{-2} \mathrm{~s}^{-1}$ in some Antarctic taxa (McMinn et al. 2010). By increasing intracellular pigment concentrations and producing accessory photosynthetic pigments (e.g. fucoxanthin and chlorophyll $c$ ), acclimation to low light can be achieved on a timescale of hours (McMinn et al. 2003; McMinn \& Martin 2013). In diatoms, this reflects the capacity to densely pack pigments and associated binding proteins and modify the structure of thylakoid membranes (Lyon \& Mock 2014). In the model microalgal taxon Fragilariopsis cylindrus, even a small reduction in ambient irradiance $(2 \mu \mathrm{E}$ $\mathrm{m}^{-2} \mathrm{~s}^{-1}$ versus $15 \mu \mathrm{E} \mathrm{m}^{-2} \mathrm{~s}^{-1}$ ) elicits a response whereby pigment concentrations are doubled and specific chloroplast PUFAs are produced which enhance thylakoid fluidity and the velocity of electrons within photosynthetic reaction centres (Mock \& Kroon 2002). Remarkably, algal cells growing within brine channels retain the capacity for acclimation to relatively high light (up to $350 \mu \mathrm{E} \mathrm{m}^{-2} \mathrm{~s}^{-1}$ ) (Ralph et al. 2005). The strategy for minimizing light-induced cellular damage (photoinhibition) includes non-photochemical quenching mechanisms, specifically the diatoxanthin-diadinoxathin xanthophyll cycle, which effectively limits the amount of energy that can reach photosynthetic reaction centres. Interestingly, photosynthetic performance at increased irradiance is negatively influenced by both in situ temperature and salinity (Maxwell et al. 1994; Ralph et al. 2005, 2007).

\section{UV radiation}

Despite the attenuation by snow and sea ice, microbes can be exposed to in situ UV radiation, including biologically harmful UV-B wavelengths ( $280-320 \mathrm{~nm})$. Estimates vary greatly, but between 0.3 and $13 \%$ of the surface flux is transmitted through to the bottom of the ice matrix (Trodahl \& Buckley 1990; Perovich 1993; Belzile et al. 2000; Ryan et al. 2012). Since the 1980s, significant research effort has been devoted to understanding the seasonal increase in UV radiation in polar regions (e.g. Ryan 1992; McMinn et al. 1999a; Thomas \& Dieckmann 2002a). While it appears that stratospheric ozone depletion has had a minimal effect on the annual microbial biomass generated in Antarctic coastal regions (McMinn et al. 1994; Ryan et al. 2012), at the organismal level UV-B can inhibit photosynthesis in sea-ice algae by impeding photosystem II. In addition, this wavelength band can either directly damage DNA, alter biomolecules, inactivate biochemical activities (e.g. alteration of protein synthesis), or induce the formation of reactive oxygen species (ROS), which requires an energetically expensive antioxidant response (Mallick \& Mohn 2000; Meador et al. 2002; Häder et al. 2015). Perhaps the most notable photoprotection measure exhibited by ice-associated algae is the production of mycosporine-like amino acids (MAAs). The most common suite of MAAs comprises porphyra-334 and/or shinorine together with palythine; these small secondary metabolites act as a chemical sunscreen by 
absorbing UV-B and dissipating the energy as heat (Arrigo \& Thomas 2004; Arrigo 2014). There appear to be no comparable adaptive mechanisms in sea-ice bacteria and rapid exposure to increased UV-B radiation, typical during the ice melt phase, significantly reduces metabolic activity (Martin et al. 2009).

\section{Dark survival}

The term dark survival was first coined by Antia (1976) and is used to describe the retention of viability in photoautotrophs without growth during exposure to darkness. Polar marine phytoplankton need to survive almost total darkness for up to 4 months of the year (Peck 2005; McMinn et al. 2010), but remarkably little is known about the physiological and biochemical mechanisms required for dark survival (McMinn \& Martin 2013; Lyon \& Mock 2014). Some taxa survive by producing cysts or other resting forms but in Antarctica this is limited to a few species of diatoms (Chaetoceros spp.) and a number of dinoflagellates (Taylor \& McMinn 2002). Mixotrophy, which combines both phototrophic and heterotrophic modes of energy acquisition, has been observed in ice-associated nanoflagellates, but remains somewhat ambiguous because of species-specific differences in resource requirements and variable feeding behaviours (Moorthi et al. 2009; Paterson \& Laybourn-Parry 2012). Perhaps more intriguing is that fact that facultative heterotrophy, itself is often only turned on by long periods of darkness (Legrand et al. 1998), remains unsubstantiated as a dark survival strategy for seaice diatoms (Bunt \& Lee 1972; Horner \& Alexander 1972). In situ metabolism of radio-labelled organic substrates by Arctic taxa appears to be negligible and only two studies have ever demonstrated the capacity for Antarctic diatoms to incorporate glucose and exogenous amino acids into proteins and other complex organic polymers, and even this only accounted for a maximum of $0.3 \%$ of the total carbon requirement (Palmisano \& Sullivan 1983; Rivkin \& Putt 1987). What has been clearly demonstrated is a remarkable capacity for maintenance metabolism; under non-photosynthetic conditions survival by microalgae does not require a significant drawdown of stored energy products such as mono- and polysaccharides (Martin et al. 2012; McMinn \& Martin 2013). How this is achieved at a molecular level remains unknown.

\section{Dissolved gases}

Physiological adaptations that sustain photosynthesis at high $\mathrm{O}_{2}$ and low $\mathrm{CO}_{2}$ within the confines of an alkaline environment are critically important (Arrigo \& Thomas 2004; McMinn et al. 2005, 2014). Because of the limited exchange with the underlying water column, there are a number of dramatic chemical changes that take place within the ice matrix. With respect to inorganic chemistry, precipitation of the metastable mineral ikaite $\left(\mathrm{CaCO}_{3} \cdot 6 \mathrm{H}_{2} \mathrm{O}\right)$ is currently of interest because of implications for the sea-ice-driven carbon pump, global carbon cycle and possibly even tropospheric ozone concentrations (Dieckmann et al. 2008; Rysgaard et al. 2014). Carbonate chemistry dynamics are also influenced by biological activity, which significantly influences the in situ concentration of dissolved gases $\left(\mathrm{O}_{2}, \mathrm{CO}_{2}\right)$ and $\mathrm{pH}$ (Thomas \& Dieckmann 2002b). The seasonal increase in $\mathrm{pH}$ is correlated with in situ photosynthetic carbon assimilation and the depletion of dissolved inorganic carbon (Thomas \& Papadimitriou 2003). With the exception of microbial mat communities, macrophytes and sea grasses, hyperoxia is rare in marine systems and sea-ice microbes are uniquely exposed to some of the highest dissolved oxygen concentrations on the planet (McMinn et al. 2005). As a result, photosynthetic performance and growth is compromised in ice-associated microalgae at elevated oxygen concentrations. This reflects the trend observed in all plants, whereby the competitive effect of $\mathrm{O}_{2}$ on RUBISCO (photorespiration) and generation of extra toxic oxygen species disrupts metabolism. Oxygen can accept electrons from various biomolecules resulting in the production of ROS such as superoxide $\left(\mathrm{O}_{2}^{-}\right)$, hydrogen peroxide $\left(\mathrm{H}_{2} \mathrm{O}_{2}\right)$, singlet oxygen $\left(\mathrm{l}_{2}\right)$ and hydroxyl $\left({ }^{\circ} \mathrm{OH}\right)$ radicals (Foyer et al. 1994; Rothschild \& Mancinelli 2001). These toxic photochemical products are capable of damaging cellular components such as D1 proteins within photosynthetic reaction centres as well as nucleic acids. In response, sea-ice diatoms are known to produce high-activity antioxidative enzymes, such as catalase, glutathione peroxidase and glutathione reductase, which are capable of scavenging ROS (Thomas \& Dieckmann 2002a; Arrigo \& Thomas 2004). However, other than their positive identification and presumed mode of action, very little is currently known about how sea-ice organisms utilize these enzymes to cope with oxidative stress (Thomas \& Dieckmann 2002a; Janknegt et al. 2008). In addition to intracellular ROS formation, extracellular accumulation is common within the brine channel network. Most notable is $\mathrm{H}_{2} \mathrm{O}_{2}$ which also forms photochemically in the upper regions of the ice and can reach concentrations up to $0.1 \mu \mathrm{M}$ (King et al. 2005). In some diatom genera, the antioxidative defence response includes a commensalism with epiphytic bacteria, which consume the $\mathrm{H}_{2} \mathrm{O}_{2}$ produced during photosynthesis (Schriek 2000; Hünken et al. 2008). Despite the fact that shelf waters surrounding Antarctica are effective sinks for rising anthropogenic carbon emissions - a process which may in fact facilitate faster rates of photosynthesis and growth - the direct effect of $\mathrm{CO}_{2}$ on phytoplankton physiology remains poorly understood (Young et al. 2015b).

For microbes confined to the sea-ice matrix the situation is significantly different; in spring and summer photosynthetic activity significantly influences sea-ice $\mathrm{CO}_{2}$-carbonate chemistry (Thomas \& Papadimitriou 2003; Delille et al. 2007; McMinn et al. 2014). Although the number of assessments carried out within natural ice in both the Arctic and Antarctic remains limited, the available data describe an in situ trend of very low $p \mathrm{CO}_{2}(<100 \mu \mathrm{atm})$ and high $\mathrm{pH}(>8.6)$ during spring months (see Bates et al. 2014). However, this dynamic is complex and unpredictable because it reflects both the physical conditions (e.g. temperature, salinity, ice thickness, ikaite formation/dissolution) and biological processes (e.g. primary production and respiration) (Bates et al. 2014). Limited experimental work with microalgae present near the surface of the ice 
has shown that if cells are incubated at a constant $\mathrm{pH}$ of $\sim 8.0$, then an increase in $\mathrm{CO}_{2}$ availability results in a growth increase of approximately $20 \%$. However, if microbes acclimated to this region of the ice are exposed to decreasing $\mathrm{pH}(<\sim 7.2)$, then $\mathrm{CO}_{2}$ at high concentrations has been shown to reduce growth rates by almost 50\% (McMinn et al. 2014) (Fig. 1).

\section{Nutrients}

Along with the biological components, the incorporation of dissolved inorganic nutrients, including nitrate, ammonium, phosphate, silicate and trace metals such as iron takes place during initial ice formation. Zones of high biological production are governed by microbial-community succession and the re-supply of nutrients, which is highly variable with respect to vertical stratification within the ice matrix (McMinn et al. 1999a, b; Fritsen et al. 2001). In contrast to what might be expected, in situ nutrient concentrations generally remain high and are seldom growth-limiting for biological assemblages. This is particularly the case at the ice/water interface where there is continuous nutrient exchange with the underlying seawater (Thomas \& Papadimitriou 2003; Arrigo 2014). In the strict absence of biological activity, the concentration of nutrients is proportional to brine salinity and can therefore be exceptionally high in the coldest regions that are found near the upper surface of the ice (Werner et al. 2007). Despite the recycling of organic matter by bacteria which promotes the accumulation of phosphate and ammonium, the seasonal assimilation of nutrients by microalgae in regions of the matrix that are isolated from nutrient re-supply strongly influence the nutrient: salinity relationship (e.g. Dieckmann et al. 1991; Riedel et al. 2007) and this can lead to localized nutrient exhaustion (McMinn et al. 1999b; Fritsen et al. 2001), particularly during the period just prior to ice melt, which coincides with the highest in situ microbial biomass (Lizotte \& Sullivan 1992; Günther et al. 1999). In general, the supply and production of nutrients is greater than the apparent capacity for utilization within the sea-ice system (Fritsen et al. 2001; Thomas \& Papadimitriou 2003). This is significant because sea-ice algae and bacteria appear to be unable to sequester either inorganic substrates or organic compounds with decreasing temperature because of lowered substrate affinity (Nedwell 1999; Pomeroy \& Wiebe 2001). Higher substrate concentrations are typically required at the lower end of a species optimum growth temperature, and growth inhibition can be reversed if higher substrate concentrations become available (Thomas \& Dieckmann 2002b).

\section{The potential for life in extra-terrestrial ice-covered oceans}

The current search for extraterrestrial life is the search for life as we know it; life comprised of organic molecules in liquid water (Chyba et al. 2000). However, conditions beyond the protective confines of Earth's atmosphere are likely to challenge any form of life - space is a nutritional wasteland with respect to water and organic compounds and is subject to extreme cold, solar wind, galactic radiation, space vacuum and negligible gravity (Chyba \& Phillips 2001; Rothschild \& Mancinelli 2001; Horneck et al. 2010). As a field of research, microbial ecology has always been juxtaposed between scales - the requirement to resolve life processes at the cellular level, while at the same time qualifying, and preferably quantifying, the contribution of microbes to global biogeochemistry (Azam \& Malfatti 2007). At the astronomical scale, this challenge is amplified significantly. Despite the growing list of exoplanets and the prospect for life on suspected ocean world's, targeting 'cosmic life rafts' within the vastness of space is far from trivial. However, initial efforts have been highly productive with respect to the survival of model microbial strains that have been exposed to the effects of radiation, desiccation and vacuum environments using ground-based spaceflight analogues, space shuttle missions and the space stations (see Horneck et al. 2010 for an excellent review). Much of this work has focused on the survival of spores exposed to space vacuum and Solar UV. Extending the survival envelope to other celestial objects is, for the time being, a theoretical undertaking, but the adaptive capacity of ice-associated eutectophiles is such that much of Europa and Enceladus can be considered plausible habitats for Earth-like life.

The satellites of the outer Solar System are highly variable. While most moons are composed of rock and ice, rock that is separated from ice due to tidal-based heating that leads to the formation of clearly defined liquid oceans is only a feature on some moons (Schubert et al. 2010). With respect to exobiology, Jupiter's moon Europa and Saturn's moon Enceladus may be considered the most favourable modern habitats for complex organic chemistry and possibly life. Potential ecological niches on both moons comprise the ice layer, brine oceans and seafloor environments (Cottin et al. 2015).

\section{Europa}

Spectroscopic analysis coupled with observations of the geology and magnetic field measurements reveal that below the icy exterior is an ocean that is in direct contact with the moon's rocky seafloor (Chyba \& Phillips 2002). In principle, interior heat is released from the moon's core, which may contribute to organic processes that are comparable with the hydrothermal vent systems on Earth (Cottin et al. 2015). The exact thickness of Europa's icy exterior and ocean depth remains unknown. Estimates for the outer shell range from $\sim 3$ to $>30 \mathrm{~km}$ (Greenburg et al. 2000; Kerr 2001; Hand \& Chyba 2007; Schmidt et al. 2011) but mounting evidence suggests that ocean water reaches the moon's surface via tidally driven stress fractures (Schmidt et al. 2011; Hand \& Brown 2013; Roth et al. 2014). The formation of these features in the crust are likely to be unpredictable, but models infer both their persistence for tens of thousands of years and the potential for daily inundation of seawater in the temperature range of -4 to $0^{\circ} \mathrm{C}$ (Greenburg et al. 2000; Melosh et al. 2004). With respect to habitability, temperature and the chemical composition of the ocean are important considerations, not least because of their influence on the depth of the ice-water interface. At present, the salt concentration and composition of the subsurface ocean remains poorly constrained; magnesium $\left(\mathrm{Mg}^{2+}\right)$ should 


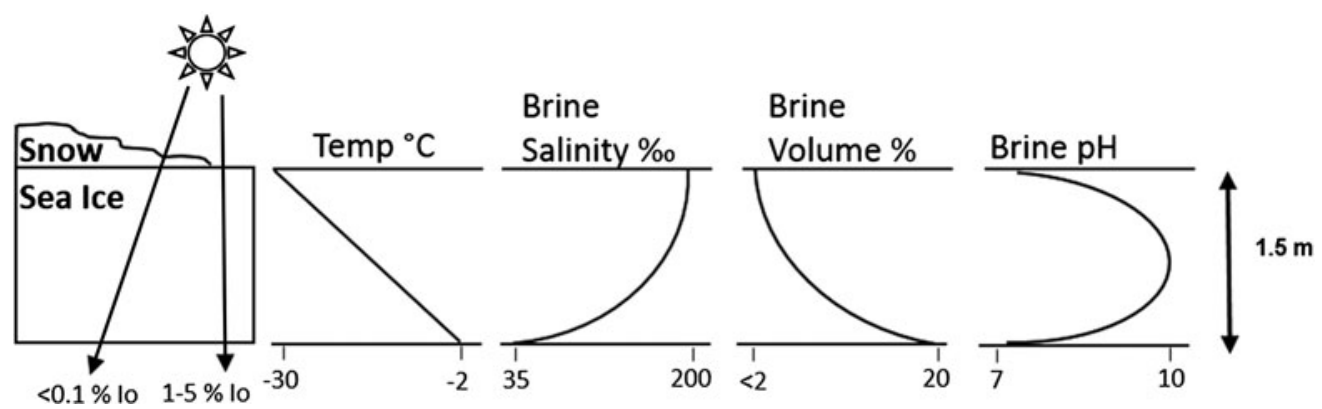

Fig. 1. Schematic representation of the physicochemical gradients that occur within annual polar sea ice. Note that snow cover significantly reduces incident irradiance $\left(I_{0}\right)$. In situ carbonate chemistry dynamics are complex and highly variable; the trend in $\mathrm{pH}$ is shown to indicate the range of microbial niches present in sea ice due to gradients in physicochemical conditions. Adapted from Eicken (1992), Thomas \& Dieckmann (2002a) and Hare et al. (2013).

be the dominant cation and sulphate $\left(\mathrm{SO}_{4}^{2-}\right)$ the dominant anion, but the relative abundance of sodium chloride $(\mathrm{NaCl})$ and the bulk salinity have yet to be resolved. Europa's ocean could be a $\sim 100 \mathrm{~km}$ deep source of nearly fresh water or an ocean with a $\mathrm{NaCl}$ concentration close to the point of saturation (Hand \& Chyba 2007). Remarkably, a recent wholemoon model simulation of the thermal evolution of Europa predicts a relatively well mixed ocean with a salt concentration of $\sim 35 \mathrm{ppt}$, essentially comparable to oceans on Earth (Travis et al. 2012). The brines that infiltrate the ice-cover exterior could be high in magnesium sulphate $\left(\mathrm{MgSO}_{4}\right)$, sodium sulphate $\left(\mathrm{Na}_{2} \mathrm{SO}_{4}\right)$ and sodium carbonate $\left(\mathrm{Na}_{2} \mathrm{CO}_{3}\right)$, but also potentially sulphuric acid. With respect to the surface of Europa, significant reservoirs of oxygen have been spectrally detected in the form of $\mathrm{H}_{2} \mathrm{O}_{2}$, sulphuric acid $\left(\mathrm{H}_{2} \mathrm{SO}_{4}\right)$ and carbon dioxide $\left(\mathrm{CO}_{2}\right)$; molecular oxygen and ozone are inferred on the basis of Europa's tenuous oxygen atmosphere (Gaidos et al. 1999). Important biogenic materials such as sulphur may be continually ejected and transported from Io to Europa, however bombardment by energetic charged particles in the Jovian magnetosphere is significant and no known organism could live within $\sim 10 \mathrm{~cm}$ of the surface (Greenburg et al. 2000).

\section{Enceladus}

One of the defining characteristics of Saturn's moon Enceladus is the cryovolcanism, which results in plumes of vapour and icy particles being ejected into space from the moon's South Pole region (Schmidt et al. 2008; Postberg et al. 2009; Porco et al. 2014). The gas plume is primarily dominated by water vapour, but also contains approximately $5 \% \mathrm{CO}_{2}, 1 \% \mathrm{CH}_{4}, 1 \%$ ammonia $\left(\mathrm{NH}_{3}\right)$ and small quantities of heavier hydrocarbons and organic molecules. The plume-associated particles are, for the most part water ice, but also contain dust in the form of salt-rich ice grains, specifically $\mathrm{NaCl}$, and silicon-rich, nanometre-sized particles, both of which provide compelling evidence for a subsurface ocean (Postberg et al. 2009, 2011; Hsu et al. 2015). Although many details remain unclear, the favoured mechanism for the formation and maintenance of a liquid layer on Enceladus is tidal heating driven by the moons eccentric orbit (Spencer \& Nimmo 2013; Porco et al. 2014). Until recently, this body of water was thought to comprise a regional south polar sea, but a recent interpretation of data collected by the Cassini spacecraft infers the presence of a global subsurface ocean (Thomas et al. 2015). The relation of the ocean to both the inner core and outer shell of the moon have yet to be defined, but modelling carried out by Thomas et al. (2015) suggests that the ocean is $26-31 \mathrm{~km}$ thick, underlying an ice crust that is $21-26 \mathrm{~km}$ thick. At the south polar region of Enceladus, the ice thickness is predicted to be $\leq 13 \mathrm{~km}$. Analysis of the plume has provided significant insight into the interior of Enceladus; because silica colloids aggregate and precipitate quickly at high ionic strength, silica nanoparticles can be used to probe the $\mathrm{pH}$, salinity and water temperature at the bottom of the ocean, while the micrometre-sized dust grains infer composition and thermal processes at the ice-water interface and in the vent complex (Spencer \& Nimmo 2013). At the core-ocean interface, the temperature could be $>90^{\circ} \mathrm{C}$ with a $\mathrm{pH}>8.5$ (Hsu et al. 2015). However, estimates for the subsurface ocean $\mathrm{pH}$ vary significantly; Hsu et al. (2015) derived values of $8.5-10.5$ and a salinity of $<40 \mathrm{ppt}$ from plume nanoparticle analysis, while a thermodynamic model of carbonate speciation produced by Glein et al. (2015), which was linked to plume analysis of $\mathrm{CO}_{2}$ and carbonate salts, alludes to a 'soda ocean' ( $\mathrm{pH} \sim 11-12)$. This latter interpretation is highly significant because of the inference to serpentinization, a water-rock reaction that leads to the generation of $\mathrm{H}_{2}$. Whether this is a contemporary geothermal dynamic remains unclear (Sekine et al. 2015), but $\mathrm{H}_{2}$ is a geochemical fuel that can support both the abiotic and biological synthesis of organic molecules (Glein et al. 2015). The temperature gradient across the subsurface ocean remains equally speculative with estimates ranging from -3 to $-23^{\circ} \mathrm{C}$ (Nimmo et al. 2007; Parkinson et al. 2008). Within the ice shell of Enceladus, specifically at the plume source-water surface, the temperature is predicted to be $\sim 0^{\circ} \mathrm{C}, \mathrm{pH} \sim 8.5-9$ and salinity $>5 \mathrm{ppt}$ (Postberg et al. 2009). As is the case with Europa, direct measurements of liquids may be possible in the future, but drilling missions will be complex and costly (Dachwald et al. 2014).

Europa and Enceladus are both compelling targets for astrobiological exploration. The inferred presence of liquid oceans that have persisted over geological timescales is intriguing, even if they actually prove to be a common occurrence in our 
Solar System (Chyba \& Hand 2001; Stevenson et al. 2015). Life as we know it is expected to be absent on the surface of Europa and Enceladus, precluded by ionizing radiation and extremely low temperatures. Hydrothermal vents may or may not exist (Chyba 2000; Hsu et al. 2015) and photosynthesis is not possible under ice that is kilometres thick. Six elements in the Periodic Table are ubiquitous in the macromolecules of life on Earth: C, H, N, O, P and S; availability of these biogenic elements is tightly coupled with habitability in the microbial domains of life (Cockell et al. 2016). With respect to the relative abundance of CHNOPS on the moons of Saturn and Jupiter, very little is known (Chyba \& Phillips 2001, 2002), although various pathways have been proposed whereby chemical energy is made available in the form of disequilibrium concentrations of redox reactants produced on the surface of both Europa (e.g. Gaidos et al. 1999; Chyba 2000; Chyba \& Hand 2001; Chyba \& Phillips 2001) and Enceladus (Parkinson et al. 2008). The only known form of carbon on Europa's surface is $\mathrm{CO}_{2}$, but the radiolytic chemistry that results from bombardment by energetic electrons and ions trapped within the Jovian magnetic field has shown, at least experimentally, that carbon could be partitioned into reservoirs of $\mathrm{CO}_{2}, \mathrm{CO}$ and $\mathrm{H}_{2} \mathrm{CO}_{3}$ with an approximate ratio of $[5: 1: 1]$, respectively (Hand et al. 2007). On Enceladus, deposits of $\mathrm{H}_{2} \mathrm{O}_{2}, \mathrm{NH}_{3}$ and $\mathrm{CO}_{2}$ are evident, which appear to originate from the fraction of plume material that is not lost to space (Parkinson et al. 2008). Validating sources of free energy on either moon remains challenging (Gaidos et al. 1999; Chyba \& Phillips 2002), as is qualifying possible metabolic life processes or ecosystem dynamics. However, celestial bodies that are in all probability hostile to life in general, may still harbour biologically permissive domains.

The fracture networks in the icy exterior of both moons appear to actively exchange material from the oceanic subsurface through to the outer exterior of the ice, a process which could reflect the presence of brines at shallow depths over diapiric plumes of relatively warm ice. Whether tidally driven water migrates diurnally through fissures to the surface remains controversial (Chyba \& Phillips 2001); however, the recently proposed theory that Europa's ice shell comprises a mobile plate tectonic-like system overlying warmer convecting ice (Kattenhorn \& Prockter 2014) infers dramatic subduction events. This dynamic has important implications for both fluid transport and the possibility of a microbial 'stasis zone'. Microbes present in more favourable regions such as the ice/ water interface or subsurface ocean that were forced upwards and exposed to near-surface temperatures would conceivably flash-freeze. This process of vitrification does not occur naturally on Earth, but it is highly relevant to astrobiology because of the potential for extreme cold to induce a state of suspended animation, similar to the process of cryopreservation. The prospect that this process could be reversed - a return to metabolic activity correlated with tectonic processes - is highly speculative, but it is also intriguing. Importantly, future missions to icy moons might not require that probes drill through tens of kilometres of ice to gain an insight into the potential biology of subsurface oceans. Stress-related fissures in the ice are complex, and for the time being our understanding of the geophysics is based largely on theoretical modelling. For example, tidal-tectonic dynamics and crustal recycling models for Europa infer that fractures are transient features that only remain active for $10^{4}-10^{6}$ years (Greenburg et al. 2000). While transient near-surface liquid water environments that permit life are considered feasible (Gaidos \& Nimmo 2000; Greenburg et al. 2000), there is limited data for either moon with which to accurately resolve fracture network topography, specifically ice permeability and brine volume (but see Kargel et al. 2000). Whether biologically available nitrogen, sulphur and phosphorus are present is unknown. Availability of these elements requires that they are present in the rocky core and that convective mechanisms drive strong subsurface circulation. In the absence of hydrothermal vent activity that might facilitate the exchange of elements or even support seafloor ecosystems, a fundamental requirement for the presence of life in a subsurface ocean would be the significant surface-toocean transfer of oxidants or organics (Chyba 2000; Chyba \& Hand 2001; Hand et al. 2007). Clearly, the physiological demands on an in situ microbial consortia would be exceptional, regardless of whether fracture zones provided a point of origin for life, or ephemeral habitats reflecting the passive transport of organisms from the ocean below.

The potential for significant tidal-driven movement of fluids through the fracture network is an important point of difference in the comparison with Earth's sea-ice ecosystem. Additional caveats include habitat scale (metres versus kilometres) and localized physicochemical variability (isolated brine channels versus fissures with unknown dimensions). Pressure is also an important consideration. At the ice/water interface on Europa this is likely to be between 84 and 205 MPa (Kargel et al. 2000), but this is well within the range of pressure resistance that cellular life can survive (see Vanlindt et al. 2011). In very general terms, the lower biological temperature threshold of approximately $-20^{\circ} \mathrm{C}$ would allow microbial life to exist at the ice/water interface on Europa and Enceladus and extend upwards into the overlying ice, perhaps by as much as $5 \mathrm{~km}$ (Nimmo \& Manga 2009). In accordance with known biology, microbes would not be able to maintain membrane fluidity in significantly colder regions of the ice and the production of cold-adapted enzymes and cryoprotectants would be impaired. If fracture topography dictates fine-scale thermal isolation and chloride salts are abundant, then temperatures below $-20^{\circ} \mathrm{C}$ would result in the formation of hypersaline brines exceeding 200\% and limit the microbial capacity for extracellular buffering. However, sea-ice microbes could tolerate the salinity regime that spans the ice/water interface and approximately $5 \mathrm{~km}$ of ice. The assumption here is that salinity is governed by temperature; while bulk salinity could be similar to Earth's oceans, the relative abundance of salts comprising the reservoirs on both moons has yet to be resolved and interpretation of chemical gradients is speculative. Indeed, some models for Europa infer a process of continued acidification that may have formed an ocean of eutectic sulphuric acid unlikely to be conducive to any known form of life (Kargel et al. 2000) (Fig. 2). 

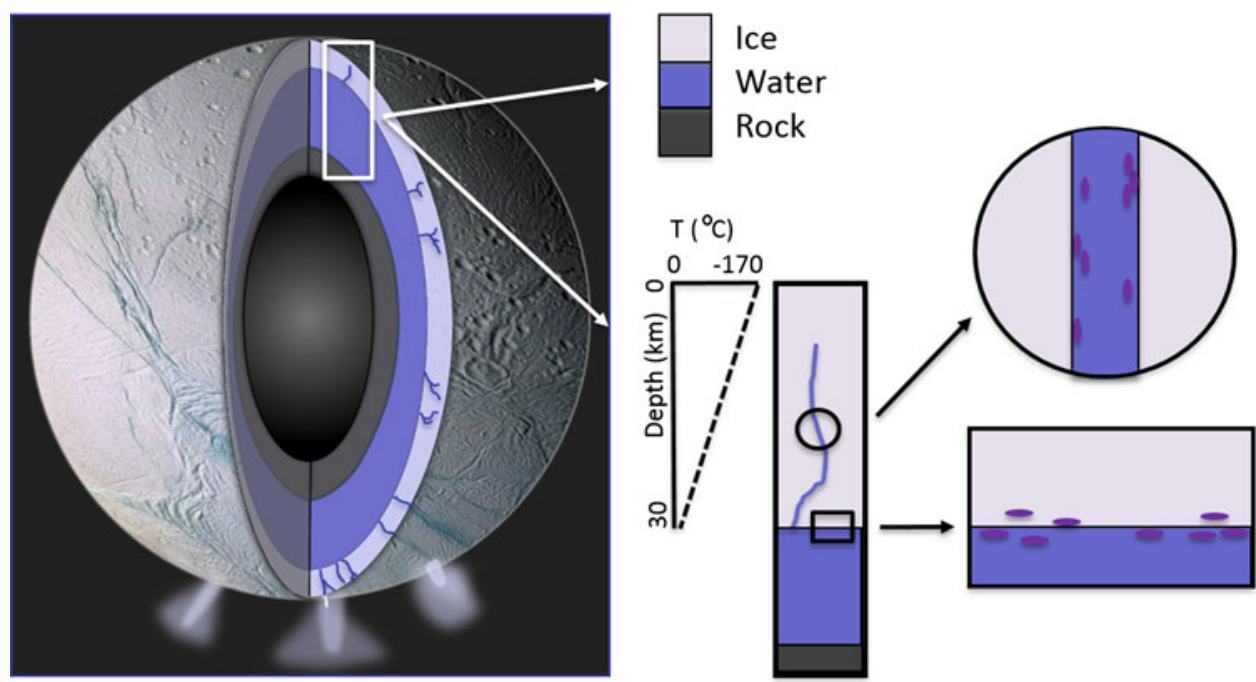

Fig. 2. Conceptual model of an ice fissure and the ice/water interface on Europa or Enceladus. These represent two ecological niches that Earthbased eutectophiles could potentially inhabit.

Table 3. Pathways of biogeochemical interest for Europa and Enceladus identified by metabolic inference of ice-associated bacteria

\begin{tabular}{|c|c|c|c|c|c|c|}
\hline Function & Metabolic pathway $^{\mathrm{a}}$ & $\begin{array}{l}\text { Reactant } \\
\text { requirements }\end{array}$ & $\begin{array}{l}\text { Ice-associated } \\
\text { bacterial genera }\end{array}$ & $\begin{array}{l}\text { Relative } \\
\text { abundance } \\
\text { in sea ice }\end{array}$ & $\begin{array}{l}\text { Reactant } \\
\text { requirements } \\
\text { met on Europa }\end{array}$ & $\begin{array}{l}\text { Reactant } \\
\text { requirements met } \\
\text { on Enceladus }\end{array}$ \\
\hline $\mathrm{C}_{1}$ metabolism & Formaldehyde oxidation II & $\mathrm{CH}_{2} \mathrm{O}$ & Colwellia, Octadecabacter & High & Yes & Yes \\
\hline $\mathrm{CO}_{2}$ fixation & $\begin{array}{l}\mathrm{CO}_{2} \text { fixation into } \\
\text { oxaloacetate }\end{array}$ & $\mathrm{H}_{2} \mathrm{O} ; \mathrm{H}+$ & $\begin{array}{l}\text { Polaribacter, } \\
\text { Pseudoalteromonas, } \\
\text { Psychrobacter }\end{array}$ & High & Yes & Yes \\
\hline $\begin{array}{l}\text { Choline } \\
\text { degradation }\end{array}$ & Choline degradation I & $\mathrm{C}_{5} \mathrm{H}_{14} \mathrm{NO}$ & $\begin{array}{l}\text { Colwellia, Glaciecola, } \\
\text { Octadecabacter }\end{array}$ & High & Unknown & Unknown \\
\hline $\begin{array}{l}\text { Glycine betaine } \\
\text { production }\end{array}$ & $\begin{array}{l}\text { Glycine betaine biosynthesis } \\
\text { I }\end{array}$ & $\mathrm{C}_{5} \mathrm{H}_{14} \mathrm{NO}$ & $\begin{array}{l}\text { Colwellia, Octadecabacter, } \\
\text { Psychrobacter }\end{array}$ & High & Unknown & Unknown \\
\hline $\begin{array}{l}\text { Halocarbon } \\
\text { degradation }\end{array}$ & $\begin{array}{l}\text { 2-chlorobenzoate } \\
\text { degradation }\end{array}$ & $\mathrm{C}_{7} \mathrm{H}_{4} \mathrm{Cl}$ & Psychrobacter & High & Unknown & Unknown \\
\hline $\begin{array}{l}\text { Mercury } \\
\text { conversion }\end{array}$ & $\begin{array}{l}\text { Phenylmercury acetate } \\
\text { degradation }\end{array}$ & $\mathrm{C}_{8} \mathrm{H}_{8} \mathrm{O} 2 \mathrm{Hg} ; \mathrm{H}^{+}$ & $\begin{array}{l}\text { Psychrobacter, } \\
\text { Octadecabacter }\end{array}$ & High & Unknown & Unknown \\
\hline Nitrogen fixation & Nitrogen fixation & $\mathrm{N}$ & Coraliomargarita & Low & Unknown & Yes \\
\hline Sulfite oxidation & Sulfite oxidation II/III & $\mathrm{SO}_{3}$ & Pelagibacter, Cellvibrio & Low & Probably & Unknown \\
\hline Sulfate reduction & Sulfate reduction IV/V & $\mathrm{SO}_{4}^{2-}$ & $\begin{array}{l}\text { Psychrobacter, Halomonas, } \\
\text { Vibrio }\end{array}$ & Varies & Yes & Yes \\
\hline Denitrification & Nitrate reduction I/VII & $\mathrm{NO}_{3}$ & Colwellia, Cellvibrio & Varies & Unknown & Unknown \\
\hline
\end{tabular}

${ }^{\mathrm{a}}$ Pathway names as described by the MetaCyc ontology.

Adapted from Bowman (2013, 2015) and Cockell et al. (2016).

Proposed metabolic pathways for subsurface ecosystems on Europa include methanogenesis, sulphur reduction and iron oxide reduction (Gaidos et al. 1999; Chyba 2000; Cockell et al. 2016). Sulphur reduction is of particular relevance because recent analysis of $16 \mathrm{~S}$ rRNA genes from ice-associated bacteria infers that this process, although previously unknown, could be taking place within sea ice (Bowman 2015). A subsurface ecology driven by the reaction $\mathrm{HCHO}+\mathrm{O}_{2} \rightarrow \mathrm{H}_{2} \mathrm{O}+$ $\mathrm{CO}_{2}$ is of interest because neither photosynthesis nor hydrothermal vent activity is required to sustain life (Chyba \& Phillips 2001). On one level, any emphasis on biological production that accounts for ecosystem processes approaching the 'planetary scale' is compelling. For example, substantive estimates infer that $\sim 10^{9} \mathrm{~mol} \mathrm{y}^{-1}$ equivalent molecular oxygen $\left(\mathrm{O}_{2}\right)$ could reach Europa's ocean through radiolysis and ice shell recycling, which in principle could produce $\sim 10^{8}$ $10^{9} \mathrm{~g} \mathrm{y}^{-1}$ of biomass (Chyba \& Hand 2001). From a microbial perspective, this approach is somewhat misleading. The constraints on inhabiting extreme environments on Earth illustrates that although microbial assemblages are often capable of growing quickly, as physiological thresholds are approached resource dependency increases. Because these habitats are often characterized by multiple physicochemical stressors, limitations to growth are exacerbated at physiological extremes, which leads to patchy spatial and temporal distributions. The sea-ice ecosystem is a particularly useful exemplar: there is a 
finite temporal window for photosynthetic metabolism within spatially confined brine channels that have a finite concentration of nutrients and limited capacity for gas exchange. When viewed in this context, life in extreme environments is inherently resource limited. Conversely, organisms in these environments are inherently resourceful as evidenced by their capacity for rapid opportunistic growth. Biologically available elements notwithstanding, the light required by microalgae for photosynthesis is so minimal that several authors have alluded to the possibility of light-driven metabolism associated with tidal dynamics and ice fissures on Europa (Gaidos \& Nimmo 2000; Greenburg et al. 2000). However due to the process of vitrification described earlier, this is considered by most to be theoretically impossible.

We bring this review to a close by highlighting the fact that there are other metabolic pathways associated with the sea-ice ecosystem that do not require Solar radiation, all other factors being permissive of life. Because gene expression remains underexplored and a defined framework that links microbial community function with biogeochemical drivers is lacking, Bowman (2015) recently used a technique called metabolic inference to screen $16 \mathrm{~S}$ rRNA gene libraries to reveal metabolic plasticity in ice-associated prokaryotes (see Bowman \& Ducklow 2015). This novel tool for identifying metabolic pathways has ranging implications for astrobiology. In Table 3, we cross-reference pathways of high biogeochemical interest with the relative abundance of bacterial genera in sea ice (Bowman 2013), and provide a simplistic indicator for whether Europa and Enceladus could support the biogeochemistry. It is important to note that the last two columns of Table 3 only refer to the requirement for a specific metabolic reactant being present and that few other requirements for the pathways, much less the organisms, are met. It will be necessary to qualify each pathway under controlled laboratory conditions, but the identification of new targets for metabolic profiling represents a significant step in framing the adaptive capacity of sea-ice microbes to multi-stressor environments.

\section{Conclusions}

The search for life beyond Earth requires a robust definition of the physical and chemical boundaries for Earth-based extremophiles, and for prebiotic chemistry to account for the original synthesis of life (Dartnell 2011). Because of these constraints on known biology and the sheer magnitude of the Universe, habitability of any celestial object will only be confirmed by showing inhabitation (McKay 2014). Although far from prophetic, this statement by McKay (2014) in describing the availability and relative importance of common elements in the Universe applies equally well to the fact that no definite limits for life on Earth have been established for any given extreme (Harrison et al. 2013; Cottin et al. 2015). Furthermore, the response of extremophiles to multiple physiological stressors currently impedes the search for extra-terrestrial life because we lack a mechanistic framework that links the capacity for biological adaptation with environmental variability (Dartnell 2011; Harrison et al. 2013). Equally challenging, is the requirement to characterize the theoretical limits for supporting biological processes that are distinct from the limits imposed on Earth-based analogues. While this may initially seem idiosyncratic, an important transitional step will be to undertake experimental work across multiple physicochemical extremes and couple this with research that contrasts the limits of Earth's biosphere with extra-terrestrial environments of interest (Harrison et al. 2013). Viewed in this context, environments that are not usually encountered on Earth - or even ever can be framed within the context of hypotheses for testing habitat variability and the potential distribution of life in the Universe (Cockell 2014). The value of the sea-ice ecosystem to astrobiology is the in situ gradient of physicochemical extremes. This habitat represents the closest Earth analogue to the likely fracture network on Europa and Enceladus and eutectophiles are highly relevant biological reference organisms for facilitating further research and planning for future exploration to these moons.

\section{Acknowledgements}

We gratefully acknowledge the anonymous reviewers for their insightful and constructive comments, which improved the manuscript significantly. We also thank Fraser Kennedy for assistance with graphic design.

\section{References}

Anderson, S.P. (2016). Ocean worlds exploration program: new budget calls for missions to Europa, Enceladus and Titan. AmericaSpace. 20th May 2015. Web.

Antia, N.J. (1976). Effects of temperature on the darkness survival of marine microplanktonic algae. Microb. Ecol. 3, 41-54.

Arrigo, K.R. (2014). Sea ice ecosystems. Annu. Rev. Mar. Sci. 6, 439-467.

Arrigo, K.R. \& Sullivan, C.W. (1992). The influence of salinity and temperature covariation on the photophysiological characteristics of Antarctic sea ice microalgae. J. Phycol. 28, 746-756.

Arrigo, K.R. \& Thomas, D.N. (2004). Large scale importance of sea ice biology in the Southern Ocean. Antarct. Sci. 16, 471-486.

Aslam, S.N., Cresswell-Maynard, T., Thomas, D.N. \& Underwood, G.J. (2012a). Production and characterisation of the intra- and extracellular carbohydrates and polymeric substances (EPS) of three sea-ice diatom species, and evidence for a cryoprotective role for EPS. J. Phycol. 48, 1494-1509.

Aslam, S.N. et al. (2012b). Dissolved extracellular polymeric substances (dEPS) dynamics and bacterial growth during sea ice formation in an ice tank study. Polar Biol. 35, 661-676.

Azam, F. \& Malfatti, F. (2007). Microbial structuring of marine ecosystems. Nat. Rev. Microbiol. 5, 782-791.

Bakermans, C. \& Skidmore, M. (2011). Microbial respiration in ice at subzero temperatures $\left(-4^{\circ} \mathrm{C}\right.$ to $\left.-33^{\circ} \mathrm{C}\right)$. Environ. Microbiol. Rep. 3, 774-782.

Bates, N.R. et al. (2014). Sea-ice melt $\mathrm{CO}_{2}$-carbonate chemistry in the western Arctic Ocean: meltwater contributions to air-sea $\mathrm{CO}_{2}$ gas exchange, mixed-layer properties and rates of net community production under sea ice. Biogeosciences 11, 6769-6789.

Belzile, C. et al. (2000). Ultraviolet attenuation by dissolved and particulate constituents of first-year ice during late spring in an Arctic polyna. Limnol. Oceanogr. 45, 1265-1273.

Bowman, J.P. (2013). Sea ice microbial communities. In The Prokaryotes: Prokaryotic Communities and Ecophysiology, ed. Rosenberg, E., DeLong, E.F., Lory, S., Stackebrandt, E. \& Thompson, F., pp. 193-161. Springer-Verlag, Berlin, Heidelberg. 
Bowman, J.S. (2015). The relationship between sea ice bacterial community structure and biogeochemistry: a synthesis of current knowledge and known unknowns. Elem. Sci. Anth. 3, 000072.

Bowman, J.S. \& Ducklow, H.W. (2015). Microbial communities can be described by metabolic structure: a general framework and application to a seasonally variable, depth-stratified microbial community from the coastal West Antarctic Peninsula. PLoS ONE 10, e0135868.

Bunt, J.S. \& Lee, C.C. (1972). Data on the composition and dark survival of four sea ice algae. Limnol. Oceanogr. 17, 458-461.

Casanueva, A. et al. (2010). Molecular adaptations to psychrophily: the impact of 'omic' technologies. Trends Microbiol. 18, 374-381.

Cavicchioli, R. et al. (2002). Low-temperature extremophiles and their adaptations. Curr. Opin. Biotechnol. 13, 253-261.

Celik, Y. et al. (2013). Microfluidic experiments reveal that antifreeze proteins bound to ice crystals suffice to prevent their growth. Proc. Natl. Accad. Sci. USA 110, 1309-1314.

Chang, W.S. \& Halverson, L.J. (2003). Reduced water availability influences the dynamics, development and ultrastructural properties of Pseudomonas putida biofilms. J. Bacteriol. 185, 6199-6204.

Chang, W.S. et al. (2007). Alginate production by Pseudomonas putida creates a hydrated microenvironment and contributes to biofilm architecture and stress tolerance under water-limiting conditions. J. Bacteriol. 189, 8290-8299.

Chen, Z., He, C. \& Hu, H. (2012). Temperature responses of growth, photosynthesis, fatty acid and nitrate reductase in Antarctic and temperate Stichococcus. Extremophiles 16, 127-133.

Chyba, C.F. (2000). Energy for microbial life on Europa. Nature 403, 381-382.

Chyba, C.F. \& Hand, K.P. (2001). Life without photosynthesis. Science 292, 2026-2027.

Chyba, C.F. \& Phillips, C.B. (2001). Possible ecosystems and the search for life on Europa. Proc. Natl. Acad. Sci. USA 98, 801-804.

Chyba, C.F. \& Phillips, C.B. (2002). Europa as an abode of life. Orig Life Evol. B 32, 47-68.

Chyba, C.F., Whitmire, D.P. \& Reynolds, R. (2000). Planetary habitability and the origin of life. In Protostars and Planets IV, ed. Mannings, V., Boss, A.P. \& Russell, S.S., pp. 1365-1393. University of Arizona Press, Tucson, USA.

Cockell, C.S. (2014). Types of habitat in the universe. Int. J. Astrobiol. 13, 158-164.

Cockell, C.S. et al. (2016). Habitability: a review. Astrobiology 16, 89-117.

Colangelo-Lillis, J., Eicken, H., Carpenter, S.D. \& Deming, J.W. (2016). Evidence for marine origin and microbial-viral habitability of sub-zero hypersaline aqueous inclusions within permafrost near Barrow, Alaska. FEMS Microbiol. Ecol. 92. doi: 10.1093/femsec/fiw053. First published online: 13 March 2016.

Collins, T. et al. (2008). Fundamentals of cold-adapted enzymes. In Psychrophiles: from Biodiversity to Biotechnology, ed. Margesin, R., Schinner, F., Marx, J.-C. \& Gerday, C., pp. 211-227. Springer-Verlag, Berlin, Germany.

Corliss, J.B. et al. (1979). Submarine thermal springs on the Galápagos Rift. Science 203, 1073-1083.

Cota, G.F. (1985). Photoadaptation of high Arctic algae. Nature 315, 219-222.

Cottin, H. et al. (2015). Astrobiology and the possibility of life on Earth and elsewhere. Space Sci. Rev. http://link.springer.com/article/10.1007/s11214015-0196-1

Dachwald, B. et al. (2014). IceMole: a maneuverable probe for clean in situ analysis and sampling of subsurface ice and subglacial aquatic ecosystems. Ann. Glaciol. 55, 14-22.

Dartnell, L. (2011). Biological constraints on habitability. Astron. Geophys. 52, $1.25-1.28$.

Davies, P.L. (2014). Ice-binding proteins: a remarkable diversity of structures for stopping and starting ice growth. Trends Biomed. Sci. 39, 548-555.

Davis, W.L. \& McKay, C.P. (1996). Origins of life: a comparison of theories and application to Mars. Orig. Life Evol. Biosph. 26, 61-73.

Deamer, D. \& Weber, A.L. (2010). Bioenergetcs and life's origins. Cold Spring Harb. Perspect. Biol. 2, a004929.
Decho, A.W. (1990). Microbial exopolymer secretions in ocean environments: their roles(s) in food webs and marine processes. Oceanogr. Mar. Biol. Annu. Rev. 28, 73-153.

de Duve, C. (1995). Vital Dust: the Origin and Evolution of Life on Earth. Basic Books, New York, USA.

De Maayer, P. et al. (2014). Some like it cold: understanding the survival strategies of psychrophiles. EMBO Rep. 15, 508-517.

Delille, B. et al. (2007). Biogas $\left(\mathrm{CO}_{2}, \mathrm{O}_{2}\right.$, dimethylsulfide) dynamics in spring Antarctic fast ice. Limnol. Oceanogr. 52, 1367-1379.

Deming, J.W. (2002). Psycrophiles and polar regions. Curr. Opin. Microbiol. 5, 301-309.

Deming, J.W. \& Eicken, H. (2007). Life in ice. In Planets and Life: The Emerging Science of Astrobiology, ed. Sullivan, W.T. \& Baross, J.A., pp. 292-312. Cambridge University Press, New York.

Devos, N. et al. (1998). RUBISCO adaptation to low temperatures: a comparative study in psychrophilic and mesophilic unicellular algae. $J$. Phycol. 34, 655-660.

Dieckmann, G.S. et al. (1991). The nutrient status in sea ice of the Weddell Sea during winter: effects of sea ice texture and algae. Polar Biol. 11, 449-456.

Dieckmann, G.S. et al. (2008). Calcium carbonate as ikaite crystals in Antarctic sea ice. Geophys. Res. Lett. 35, L08501.

Dumont, F., Marechal, P-A. \& Gervais, P. (2004). Cell size and water permeability as determining factors for cell viability after freezing at different cooling rates. Appl. Environ. Microbiol. 70, 268272.

Eicken, H. (1992). The role of sea ice in structuring Antarctic ecosystems. Polar Biol. 12, 3-13.

Ewert, M. \& Deming, J.W. (2013). Sea ice microorganisms: environmental constraints and extracellular responses. Biology 2, 603-628.

Ewert, M. \& Deming, J.W. (2014). Bacterial response to fluctuations and extremes in temperature and brine salinity at the surface of Arctic winter sea ice. FEMS Microbiol. Ecol. 89, 476-489.

Feller, G. (2003). Molecular adaptations to cold in psychrophilic enzymes. Cell Mol. Life Sci. 60, 648-662.

Feller, G. \& Gerday, C. (2003). Psychrophilic enzymes: hot topics in cold adaptation. Nat. Rev. Microbiol. 1, 200-208.

Foyer, C.H., Lelandais, M. \& Kunert, K.J. (1994). Photooxidative stress in plants. Physiol. Plant. 92, 696-717.

Fredrickson, K.A. \& Strom, S.L. (2009). The algal osmolyte DMSP as a microzooplankton grazing deterrent in laboratory and field trials. $J$. Plank. Res. 31, 135-152.

Fritsen, C.H. et al. (2001). Biomass, production and microhabitat characteristics near the freeboard of ice floes in the Ross Sea, Antarctica, during the austral summer. Ann. Glaciol. 33, 280-286.

Gaidos, E.J. \& Nimmo, F. (2000). Planetary science: tectonics and water on Europa. Nature 405, 637.

Gaidos, E.J., Nealson, K.H. \& Kirschvink, J.L. (1999). Life in ice-covered oceans. Science 284, 1631-1633.

Garrison, D.L. (1991). Antarctic sea ice biota. Amer. Zool. 31, 17-33.

Gerday, C. (2013). Psychrophily and catalysis. Biology 2, 719-741.

Gerday, C. et al. (2000). Cold-adapted enzymes: from fundamentals to biotechnology. Trends Biotechnol. 18, 103-107.

Gilbert, J.A. et al. (2004). Demonstration of antifreeze protein activity in Antarctic lake bacteria. Microbiology 150, 171-180.

Gilichinsky, D., Rivkina, E., Shcherbakova, V., Laurinavichuis, K. \& Tiedje, J. (2003). Supercooled water brines within permafrost - an unknown ecological niche for microorganisms: a model for astrobiology. Astrobiology 3, 331-341.

Glein, C.R., Baross, J.A. \& Waite, J.H. Jr. (2015). The pH of Enceladus' ocean. Geochim. Cosmochim. Acta 162, 202-219.

Glud, R.N. et al. (2013). High rates of microbial turnover in sediments in the deepest oceanic trench on Earth. Nat. Geosci. 6, 284-288.

Greenburg, R. et al. (2000). Habitability of Europa's crust: the role to tidaltectonic processes. J. Geophys. Res. 105, 17551-17562.

Günther, S., Gleitz, M. \& Dieckmann, G.S. (1999). Biogeochemistry of Antarctic sea ice: a case study on platelet ice layers at Drescher Inlet, Weddell Sea. Mar. Ecol. Progr. Ser. 177, 1-13. 
Häder, D-P. et al. (2015). Effects of UV radiation on aquatic ecosystems and interactions with other environmental factors. Photochem. Photobiol. Sci. 14, 108-126.

Hand, K.P. \& Brown, M.E. (2013). Keck II observations of hemispherical differences in $\mathrm{H}_{2} \mathrm{O}_{2}$ on Europa. Astrophys. J. Lett. 766, L21.

Hand, K.P. \& Chyba, C.F. (2007). Empirical constraints on the salinity of the Europan ocean and implications for a thin ice shell. Icarus 189, 424-438.

Hand, K.P., Carlson, R.W. \& Chyba, C.F. (2007). Energy, chemical disequilibrium and geological constraints on Europa. Astrobiology 7, 1006-1022.

Hare, A.A. et al. (2013). pH evolution in sea ice grown at an outdoor experimental facility. Mar. Chem. 154, 46-54.

Harrison, J.P. et al. (2013). The limits for life under multiple extremes. Trends Microbiol. 21, 204-212.

Hart, M.H. (1978). The evolution of the atmosphere of the Earth. Icarus 33, 23-39.

Hébraud, M. \& Potier, P. (1999). Cold shock response to low temperature adaptation in psychrotrophic bacteria. J. Mol. Microbiol. Biotechnol. 1, 211-219.

Hoover, R.B. \& Pikuta, E.V. (2009). Psychrophilic and psychrotolerant microbial extremophiles in polar environments. In Polar Microbiology: The Ecology, Biodiversity and Bioremediation Potential of Microorganisms in Extremely Cold Environments, ed. Bej, A.K., Aislabie, J. \& Atlas, R. M., pp. 115-156. CRC Press, USA.

Horneck, G., Klaus, D.M. \& Mancinelli, R.L. (2010). Space microbiology. Microbiol. Mol. Biol. R 74, 121-156.

Horner, R.A. \& Alexander, V. (1972). Algal populations in Arctic sea ice: an investigation of heterotrophy. Limnol. Oceanogr. 17, 454-458.

Hoyle, F. et al. (1982). Infrared spectroscopy of micro-organisms near 3,4 m in relation to geology and astronomy. Astrophys. Space Sci. 81, 489-492.

Hsu, H-W. et al. (2015). Ongoing hydrothermal activities within Enceladus. Nature 519, 207-210.

Hünken, M., Harder, J. \& Kirst, G.O. (2008). Epiphytic bacteria on the Antarctic diatom Amphiphora kufferathii Manguin cleave hydrogen peroxide produced during algal photosynthesis. Plant Biol. 10, 519-526.

Huston, A.L., Krieger-Brockett, B.B. \& Deming, J.W. (2000). Remarkably low temperature optima for extracellular enzyme activity from Arctic bacteria and sea ice. Environ. Microbiol. 2, 38-388.

Janknegt, P.J. et al. (2008). Oxidative stress responses in the marine Antarctic diatom Chaetoceros brevis (Bacillariophyceae) during photoacclimation. $J$. Phycol. 44, 957-966.

Junge, K. et al. (2002). Phylogenetic diversity of numerically important Arctic sea-ice bacteria cultured at subzero temperatures. Microb. Ecol. 43, 315-328.

Kargel, J.S. et al. (2000). Europa's crust and ocean: origin, composition, and the prospects for life. Icarus 148, 226-265.

Kasting, J.F., Whitmire, D.P. \& Reynolds, R.T. (1993). Habitable zones around main sequence stars. Icarus 101, 108-128.

Kattenhorn, S.A. \& Prockter, L.M. (2014). Evidence for subduction in the ice shell of Europa. Nat. Geosci. 7, 762-767.

Kelley, D.S. et al. (2001). An off-axis hydrothermal vent field near the MidAtlantic Ridge at $30^{\circ} \mathrm{N}$. Nature 412, 145-149.

Kerr, R.A. (2001). Putting a lid on life on Europa. Science 294, 1258 1259.

King, M.D. et al. (2005). Measurement and modelling of UV radiation penetration and photolysis rates of nitrate and hydrogen peroxide in Antarctic sea ice: an estimate of the producton rate of hydroxyl radicals in first-year sea ice. J. Phytochem. Photobiol. A 176, 39-49.

Kloster, S. et al. (2006). DMS cycle in the marine ocean-atmosphere system a global model study. Biogeosciences 3, 29-51.

Koh, Y.E. et al. (2012). Recent advances and future perspectives in microbial phototrophy in Antarctic sea ice. Biology 1, 542-556.

Kottmeier, S.T. \& Sullivan, C.W. (1988). Sea ice microbial communities (SIMCO): effects of temperature and salinity on rates of metabolism and growth of autotrophs and heterotrophs. Polar Biol. 8, 293-304.

Krell, A. et al. (2007). Regulation of proline metabolism under salt stress in the psychrophilic diatom Fragilariopsis cylindrus (Bacillariophyceae). J. Phycol. 43, 753-762.
Krembs, C. \& Deming, J.W. (2008). The role of exopolymers in microbial adaptation to sea ice. In Psychrophiles: from Biodiversity to Biotechnology, ed. Margesin, R., Schinner, F., Marx, J.-C. \& Gerday, C., pp. 247-264. Springer-Verlag, Berlin, Germany.

Krembs, C., Eicken, H., Junge, K. \& Deming, J.W. (2002). High concentrations of exopolymeric substances in Arctive winter sea ice: implication for the polar ocean carbon cycle and cryoprotection of diatoms. Deep-Sea Res. I 49, 2163-2181.

Krembs, C., Eicken, J. \& Deming, J.W. (2011). Exopolymer alteration of physical properties of sea ice and implications for ice habitability and biogeochemistry in a warmer Arctic. Proc. Natl. Acad. Sci. USA 108, 3653-3658.

Lederberg, J. (1960). Exobiology: approaches to life beyond the Earth. Science 132, 393-400.

Legrand, C., Graneli, E. \& Carlson, P. (1998). Induced phagotrophy in the photosynthetic dinoflagellate Heterocapsa triquetra. Aquat. Microb. Ecol. 15, 65-75.

Lin, L-H. et al. (2006). Long-term sustainability of a high-energy, lowdiversity crustal biome. Science 314, 479-482.

Lizotte, M.P. \& Sullivan, C.W. (1992). Biochemical composition and photosynthate distribution in sea ice microalgae of McMurdo Sound, Antarctica: evidence for nutrient stress during the spring bloom. Antarct. Sci. 4, 23-30.

Lorv, J.S.H., Rose, D.R. \& Glick, B.R. (2014). Bacterial ice crystal controlling proteins. Scientifica 2014, 976895.

Lyon, B.R. \& Mock, T. (2014). Polar microalgae: new approaches towards understanding adaptations to an extreme and changing environment. Biology 3, 56-80.

Mallick, N. \& Mohn, F.H. (2000). Reactive oxygen species: response of algal cells. J. Plant Physiol. 157, 183-193.

Margesin, R. \& Miteva, V. (2011). Diversity and ecology of psychrophilic microorganisms. Res. Microbiol. 162, 346-361.

Marlin, G. \& Kirst, G.O. (1997). Algal production of dimethyl sulphide and its atmospheric role. J. Phycol. 33, 889-896.

Martin, A., Hall, J.A. \& Ryan, K.G. (2009). Low salinity and high-level UV$\mathrm{B}$ radiation reduce single-cell activity in Antarctic sea ice bacteria. Appl. Environ. Microbiol. 75, 7570-7573.

Martin, A. et al. (2012). The physiological response to increased temperature by over-wintering sea ice algae and phytoplankton in McMurdo Sound, Antarctica and Tromsø Sound, Norway. J. Exp. Mar. Biol. Ecol. 428, 57-66.

Martin, W., Baross, J., Kelley, D. \& Russell, M.J. (2008). Hydrothermal vents and the origin of life. Nat. Rev. Microbiol. 6, 805-814.

Marx, J-C. et al. (2007). Cold-adapted enzymes from marine Antarctic organisms. Mar. Biotechnol. 9, 293-304.

Maxwell, D.P. et al. (1994). Growth at low temperature mimics high-light acclimation in Chlorella vulgaris. Plant Physiol. 105, 535-543.

McCliment, E.A. et al. (2006). Colonisation of nascent, deep-sea hydrothermal vents by a novel archaeal and nanoarchaeal assemblage. Environ. Microbiol. 8, 114-125.

McKay, C.P. (2014). Requirements and limits for life in the context of exoplanets. Proc. Natl. Acad. Sci. USA 111, 12628-12633.

McMinn, A. \& Martin, A. (2013). Dark survival in a warming world. Proc. R. Soc. B 280, 20122909.

McMinn, A., Heijnis, H. \& Hodgson, D. (1994). Minimal effects of UV-B on Antarctic diatoms over the past 20 years. Nature 370, 547-549.

McMinn, A., Ashworth, C. \& Ryan, K.G. (1999a). Growth and productivity of Antarctic sea ice algae under PAR and UV irradiances. Bot. Mar. 42, 401-407.

McMinn, A. et al. (1999b). Nutrient stress gradient in the bottom $5 \mathrm{~cm}$ of fast ice, McMurdo Sound, Antarctica. Polar Biol. 21, 220-227.

McMinn, A., Ryan, K.G. \& Gademann, R. (2003). Diurnal changes in photosynthesis of Antarctic fast ice algal communities determined by pulse amplitude modulation fluorometry. Mar. Biol. 143, 359-367.

McMinn, A., Pankowski, A. \& Delfatti, T. (2005). Effect of hyperoxia on the growth and photosynthesis of polar sea ice microalgae. J. Phycol. 41, 732-741.

McMinn, A., Martin, A. \& Ryan, K.G. (2010). Phytoplankton and sea ice algal biomass and physiology during the transition between winter and spring (McMurdo Sound, Antarctica). Polar Biol. 33, 1547-1556. 
McMinn, A. et al. (2014). The response of Antarctic sea ice algae to changes in $\mathrm{pH}$ and $\mathrm{CO}_{2}$. PLOS ONE 9, e86984.

Meador, J. et al. (2002). Seasonal fluctuation of DNA photodamage in marine plankton assemblages at Palmer Station, Antarctica. Photochem. Photobiol. 75, 266-271.

Melosh, H.J. et al. (2004). The temperature of Europa's subsurface water ocean. Icarus 168, 498-502.

Methé, B.A. et al. (2005). The psychrophilic lifestyle as revealed by the genome sequence of Colwellia psychrerythraea $34 \mathrm{H}$ through genomic and proteomic analyses. Proc. Natl. Acad. Sci. USA 102, 10913-10918.

Mock, T. (2002). In situ primary production in young Antarctic sea ice. Hydrobiology 470, 127-132.

Mock, T. \& Hoch, N. (2005). Long-term temperature acclimation of photosynthesis in steady-state cultures of the polar diatom Fragilariopsis cylindrus. Photosynth. Res. 85, 307-317.

Mock, T. \& Kroon, B.M.A. (2002). Photosynthetic energy conversion under extreme conditions I: important role of lipids as structural modulators and energy sink under $\mathrm{N}$-limited growth in Antarctic sea ice diatoms. Phytochemistry 61, 41-51.

Mock, T. \& Thomas, D.N. (2005). Recent advances in sea-ice microbiology. Environ. Microbiol. 7, 605-619.

Moorthi, S. et al. (2009). Mixotrophy: a widespread and important ecological strategy for planktonic and sea-ice nanoflagellates in the Ross Sea, Antarctica. Aquat. Microb. Ecol. 54, 269-277.

Morgan-Kiss, R.M. et al. (2006). Adaptation and acclimation of phytosynthetic microorganisms to permanently cold environments. Microbiol. Mol. Biol. R 70, 222-252.

Murray, A.E. et al. (2012). Microbial life at $-13^{\circ} \mathrm{C}$ in the brine of an icesealed Antarctic lake. Proc. Natl. Acad. Sci. USA 109, 20626-20631.

Nagy, M.L., Perez, A. \& Garcia-Pichel, F. (2005). The prokaryotic diversity of biological soil crusts in the Sonorian Desert (Organ pipe cactus national monument, AZ). FEMS Microbiol. Ecol. 54, 233-245.

Nedwell, D.B. (1999). Effect of low temperature on microbial growth: lowered affinity for substrates limits growth at low temperature. FEMS Microbiol. Ecol. 30, 101-111.

Nichols, D. et al. (1999). Developments with Antarctic microorganisms: culture collections, bioactivity screening, taxonomy, PUFA production and cold-adapted enzymes. Curr. Opin. Biotechnol. 10, 240-246.

Nimmo, F. \& Manga, M. (2009). Geodynamics of Europa's icy shell. In Europa, ed. Pappalardo, R., McKinnon, W. \& Khurana, K., pp. 381404. Arizona Press Space Science Series, USA.

Nimmo, F. et al. (2007). Shear heating as the origin of the plumes and heat flux on Enceladus. Nature 447, 289-291.

Nishiguchi, M.K. \& Somero, G.N. (1992). Temperature - and concentrationdependence of compatibility of the organic osmolyte $\beta$ dimethylsulfoniopropionate. Cryobiology 29, 118-124.

Ozturk, S. \& Aslim, B. (2010). Modification of exopolysaccharide composition and production by three cyanobacterial isolates under salt stress. Environ. Sci. Pollut. Res. 17, 595-602.

Pace, N.R. (1997). A molecular view of microbial diversity and the biosphere. Science 276, 734-740.

Palmisano, A.C. \& Sullivan, C.W. (1983). Sea ice microbial communities (SIMCO) 1. Distribution, abundance, and primary production of ice microalgae in McMurdo Sound, Antarctica in 1980. Polar Biol. 2, $171-177$.

Parkinson, C.D. et al. (2008). Habitability of Enceladus: planetary conditions for life. Orig. Life Evol. Biosph. 38, 355-369.

Parkinson, C.L. (2014). Global sea ice coverage from satellite data: annual cycle and 35-yr trends. J. Clim. 27, 9377-9382.

Paterson, H. \& Laybourn-Parry, J. (2012). Sea ice microbial dynamics over an annual ice cycle in Prydz Bay, Antarctica. Polar Biol. 35, 993-1002.

Peck, L.S. (2005). Prospects for surviving climate change in Antarctic aquatic species. Front. Zool. 2, 2-9.

Pedrós-Alió, C. (2006). Marine microbial diversity: can it be determined? Trends Microbiol. 14, 257-263.

Perovich, D.K. (1993). A theoretical model of ultraviolet light transmission through Antarctic sea ice. J. Geophys. Res. 98, 22579-22587.
Phadtare, S. (2004). Recent developments in bacterial cold-shock response. Curr. Issues Mol. Biol. 6, 125-136.

Pomeroy, L.R. \& Wiebe, W.J. (2001). Temperature and substrates as interactive limiting factors for marine heterotrophic bacteria. Aquat. Microb. Ecol. 23, 187-204.

Pomeroy, L.R. et al. (2007). The microbial loop. Oceanography 20, 28-33.

Porco, C., DiNino, D. \& Nimmo, F. (2014). How the geysers, tidal stress, and thermal emission across the south polar terrain of Enceladus are related. Astron. J. 148, 45.

Postberg, F. et al. (2009). Sodium salts in E-ring ice giants from an ocean below the surface of Enceladus. Nature 459, 1098-1101.

Postberg, F. et al. (2011). A salt-water reservoir as the source of a compositionally stratified plume on Enceladus. Nature 474, 620-622.

Ralph, P.J. et al. (2005). Short-term effect of temperature on the photokinetics of microalgae from the surface layers of Antarctic pack ice. J. Phycol. 41, 763-769.

Ralph, P.J. et al. (2007). Melting out of sea ice causes greater photosynthetic stress in algae than freezing in. J. Phycol. 43, 948-956.

Raymond, J.A. (2014). The ice-binding proteins of a snow alga, Chloromanas brevispina: probable acquisition by horizontal gene transfer. Extremophiles 18, 987-994.

Raymond, J.A. \& Kim, H.J. (2012). Possible role of horizontal gene transfer in the colonisation of sea ice by algae. PLOS ONE 7, e35968.

Raymond, J.A. \& Knight, C.A. (2003). Ice binding, recrystallization inhibition, and cryoprotective properties of ice-active substances associated with Antarctic sea ice diatoms. Cryobiology 46, 174-181.

Riedel, A. et al. (2007). Enrichment of nutrients, exopolymeric substances and microorganisms in newly formed sea ice on the Mackenzie shelf. Mar. Ecol. Progr. Ser. 342, 55-67.

Rivkin, R.B. \& Putt, M. (1987). Heterotrophy and photoheterotrophy by Antarctic microalgae: light-dependent incorporation of amino acids and glucose. J. Phycol. 23, 442-452.

Roberts, M.F. (2005). Organic compatible solutes of halotolerant and halophilic microorganisms. Saline Syst. 1, 5.

Roth, L. et al. (2014). Transient water vapour at Europa's south pole. Science 343, 171-174.

Rothschild, L.J. \& Mancinelli, R.L. (2001). Life in extreme environments. Nature 409, 1092-1101.

Runnegar, B. (1992). Evolution of the earliest animals. In Major Events in the History of Life, ed. Schopf, J.W., pp. 65-93. Jones \& Barlett Publishers, Boston, USA

Russell, N.J. (1997). Psychrophilic bacteria - molecular adaptations of membrane lipids. Comp. Biochem. Physiol. 118A, 489-493.

Russell, N.J. (2000). Toward a molecular understanding of cold activity of enzymes from psychrophiles. Extremophiles 4, 83-90.

Russell, N.J. \& Nichols, D.S. (1999). Polyunsaturated fatty acids in marine bacteria - a dogma rewritten. Microbiology 145, 767-779.

Ryan, K.G. (1992). UV radiation and photosynthetic production in Antarctic sea ice microalgae. J. Photochem. Photobiol. B: Biol. 13, 235-240.

Ryan, K.G., Ralph, P. \& McMinn, A. (2004). Acclimation of Antarctic bottom-ice algal communities to lowered salinities during melting. Polar Biol. 27, 679-686.

Ryan, K.G. et al. (2012). The effects of ultraviolet-B radiation on Antarctic sea ice algae. J. Phycol. 48, 74-84.

Rysgaard, S. et al. (2014). Temporal dynamics in ikaite in experimental sea ice. Cryosphere 8, 1469-1478.

Schmidt, B.E. et al. (2011). Active formation of 'chaos terrain' over shallow subsurface water on Europa. Nature 479, 502-505.

Schmidt, J. et al. (2008). Slow dust in Enceladus' plume from condensation and wall collisions in tiger stripe features. Nature 451, 685-688.

Schriek, R. (2000). Effects of light and temperature on the enzymatic antioxidative defence systems in the Antarctic ice diatom Entomoneis kufferathii. Ber. Polarforsch. 349, 1-129.

Schubert, G. et al. (2010). Evolution of icy satellites. Space Sci. Rev. 153, 447-484.

Sekine, Y. et al. (2015). High-temperature water-rock interactions and hydrothermal environments in the chondrite-like core of Enceladus. Nat. Commun. 6, 8604. doi: 10.1038/ncomms9604. 
Shivaji, S. \& Prakash, J.S.S. (2010). How do bacteria sense and respond to low temperature? Arch. Microbiol. 192, 85-95.

Siddiqui, K.S. \& Cavicchioli, R. (2006). Cold-adapted enzymes. Annu. Rev. Biochem. 75, 403-433.

Sievert, S.M., Kiene, R.P. \& Schulz-Vogt, H.N. (2007). The sulfur cycle. Oceanography 20, 117-123.

Soo, R.M. et al. (2009). Microbial biodiversity of thermophilic communities in hot mineral soils of Tramway Ridge, Mount Erebus, Antarctica. Environ. Microbiol. 11, 715-728.

Spencer, J.R. \& Nimmo, F. (2013). Enceladus: an active ice world in the Saturn system. Annu. Rev. Earth Planet Sci. 41, 693-717.

Spiess, F.N. et al. (1980). East Pacific Rise: hot springs and geophysical experiments. Science 207, 1421-1433.

Staley, J.T. \& Gosink, J.J. (1999). Poles apart: biodiversity and biogeography of sea ice bacteria. Annu. Rev. Microbiol. 53, 189-215.

Steele, D.J., Franklin, D.J. \& Underwood, G.J.C. (2014). Protection of cells from salinity stress by extracellular polymeric substances in diatom biofilms. Biofouling 30, 987-998.

Stevens, T.O. \& McKinley, J.P. (1995). Lithoautotrophic microbial ecosystems in deep basalt aquifers. Science 270, 450-454.

Stevenson, A. et al. (2015). Multiplication of microbes below 0.690 water activity: implications for terrestrial and extraterrestrial life. Environ. Microbiol. 17, 257-277.

Stewart, F.J. \& Fritsen, C.H. (2004). Bacteria-algae relationships in Antarctic sea ice. Antarct. Sci. 16, 143-156.

Struvay, C. \& Feller, G. (2012). Optimization to low temperature activity in psychrophilic enzymes. Int. J. Mol. Sci. 13, 11643-11665.

Stüeken, E.E. et al. (2013). Did life originate from a global chemical reactor? Geobiology 11, 101-126.

Sunda, W. et al. (2002). An antioxidant function for DMSP and DMS in marine algae. Nature 418, 317-320.

Taylor, F. \& McMinn, A. (2002). Late quaternary diatom assemblages from Prydz Bay, Eastern Antarctica. Quat. Res. 57, 151-161.

Thomas, D.N. \& Dieckmann, G.S. (2002a). Antarctic sea ice - a habitat for extremophiles. Science 295, 641-644.

Thomas, D.N. \& Dieckmann, G.S. (2002b). Biogeochemistry of Antarctic sea ice. Oceanogr. Mar. Biol. 40, 143-169.

Thomas, D.N. \& Papadimitriou, S. (2003). Biogeochemistry of sea ice. In Sea Ice - an Introduction to its Physics, Biology and Geology, ed. Thomas, D.N. \& Dieckmann, G.S., pp. 267-302. Blackwell Publishing, Oxford Publishing, Oxford, UK.

Thomas, P.C. et al. (2015). Enceladus's measured physical libration requires a global subsurface ocean. Icarus 264, 37-47.

Thomson, P.G. et al. (2004). Antarctic distribution, pigment and lipid composition, and molecular identification of the brine dinoflagellate Polarella glacialis (Dinophyceae). J. Phycol. 40, 867-873.
Torstensson, A. et al. (2013). Synergism between elevated $p \mathrm{CO}_{2}$ and temperature on the Antarctic sea ice diatom Nitzschia lecointei. Biogeosciences 10, 6391-6401.

Travis, B.J., Palguta, J. \& Schubert, G. (2012). A whole-moon thermal history model of Europa: impact of hydrothermal circulation and salt transport. Icarus 218, 1006-1019.

Trodahl, H.J. \& Buckley, R.G. (1990). Enhanced ultraviolet transmission of Antarctic sea ice during the austral spring. Geophys. Res. Lett. 17, 2177 2179.

Ugalde, S. et al. (2014). Extracellular organic carbon dynamics during a bottom-ice algal bloom (Antarctica). Aquat. Microb. Ecol. 73, 195-210.

Ulig, C. et al. (2015). In situ expression of eukaryotic ice-binding proteins in microbial communities of Arctic and Antarctic sea ice. ISME J. 9, 25372540 .

Underwood, G.J.C. et al. (2010). Distribution and composition of dissolved extracellular polymeric substances (EPS) in Antarctic sea ice. Mar. Ecol. Progr. Ser. 404, 1-19.

Underwood, G.J.C. et al. (2013). Broad-scale predictability of carbohydrates and exopolymers in Antarctic and Arctic sea ice. Proc. Natl. Acad. Sci. USA 110, 15734-15739.

van Dokkum, P.G. \& Conroy, C. (2010). A substantial population of lowmass stars in luminous elliptical galaxies. Nature 468, 940-942.

Vanlindt, D. et al. (2011). Rapid acquisition of gigapascal-high-pressure resistance by Escherichia coli. mBio 2, e00130-10.

Vaqué, D. et al. (2002). Spatial distribution of microbial biomass and activity (bacterivory and bacterial production) in the northern Weddell Sea during the austral summer (January 1994). Aquat. Microb. Ecol. 29, 107-121.

Welsh, D.T. (2000). Ecological significance of compatible solute accumulation by micro-organisms: from single cell to global climate. FEMS Microbiol. Rev. 24, 263-290.

Werner, I., Ikavalko, J. \& Schunemann, H. (2007). Sea ice algae in Arctic pack ice during late winter. Polar Biol. 30, 1493-1504.

White, P.L., Wynn-Williams, D.D. \& Russell, N.J. (2000). Diversity of thermal responses of lipid composition in the membranes of the dominant culturable members of an Antarctic fellfield soil bacterial community. Antarct. Sci. 12, 386-393.

Whitman, W.B., Coleman, D.C. \& Wiebe, W.J. (1998). Prokaryotes: the unseen majority. Proc. Natl. Acad. Sci. USA 95, 6578-6583.

Young, J.N. et al. (2015a). Slow carboxylation of Rubisco constrains the rate of carbon fixation during Antarctic phytoplankton blooms. New Phytol. 205, 172-181.

Young, J.N. et al. (2015b). Antarctic phytoplankton down-regulate their carbon-concentrating mechanisms under high $\mathrm{CO}_{2}$ with no change in growth rates. Mar. Ecol. Progr. Ser. 532, 13-28. 